\title{
Biocompatibility of Gd-Loaded Chitosan-Hyaluronic Acid Nanogels as Contrast Agents for Magnetic Resonance Cancer Imaging
}

\author{
Cecilia Virginia Gheran ${ }^{1}$, Guillaume Rigaux ${ }^{2}$, Maité Callewaert ${ }^{2}$, Alexandre Berquand ${ }^{3}$, \\ Michael Molinari $^{3}{ }^{(1 D}$, Françoise Chuburu ${ }^{2}$, Sorina Nicoleta Voicu ${ }^{1,4, *}$ and Anca Dinischiotu ${ }^{1}$ \\ 1 Faculty of Biology, Department of Biochemistry and Molecular Biology, University of Bucharest, \\ 050095 Bucharest, Romania; virginia.gheran@bio.unibuc.ro (C.V.G.); anca.dinischiotu@bio.unibuc.ro (A.D.) \\ 2 Institut de Chimie Moléculaire de Reims, CNRS UMR 7312, Université de Reims Champagne-Ardenne \\ URCA, F-51685 Reims CEDEX 2, France; guillaume.rigaux@univ-reims.fr (G.R.); \\ maite.callewaert@univ-reims.fr (M.C.); francoise.chuburu@univ-reims.fr (F.C.) \\ 3 Laboratoire de Recherche en Nanosciences-EA 4682, Plate-forme Nano'Mat, Université de Reims \\ Champagne-Ardenne URCA, F-51685 Reims CEDEX 2, France; alexandre.berquand@univ-reims.fr (A.B.); \\ michael.molinari@univ-reims.fr (M.M.) \\ 4 Faculty of Pharmacy, Department of Pharmacy, Titu Maiorescu University, 004051 Bucharest, Romania \\ * Correspondence: sorina.voicu@bio.unibuc.ro; Tel.: +40-21-3181575
}

Received: 12 February 2018; Accepted: 25 March 2018; Published: 28 March 2018

\begin{abstract}
Although the research on nanogels incorporating Gd chelates for theranostic applications has grown exponentially in recent years, knowledge about their biocompatibility is limited. We compared the biocompatibility of Gd-loaded hyaluronic acid-chitosan-based nanogels (GdCACCS-TPP/HA) with two chitosan concentrations (2.5 and $1.5 \mathrm{mg} \cdot \mathrm{mL}^{-1}$ respectively) using SVEC4-10 murine lymph node endothelial cells. The sulforhodamine B method and released lactate dehydrogenase (LDH) activity were used as cell viability tests. Reactive oxygen species (ROS), reduced glutathione (GSH) and malondialdehyde (MDA) were measured by spectrophotometric and fluorimetric methods. Nrf-2 protein expression was evaluated by Western blot analysis and genotoxicity by alkaline comet assay. After $24 \mathrm{~h}$, the cells viability was not affected by all types and doses of nanogels. The increase of ROS induced a low decrease of GSH concentration and a time-dependent raise of MDA one was produced by citric GdDOTA CCS-TPP/HA with a chitosan concentration of $1.5 \mathrm{mg} \cdot \mathrm{mL}^{-1}$, at the highest dose applied. None of the tested nanogels induced changes in Nrf-2 protein expression. A slight but significant genotoxic effect was caused only by citric GdDOTACCS-TPP/HA where CS concentration was $1.5 \mathrm{mg} \cdot \mathrm{mL}^{-1}$. Our results showed a better biocompatibility with lymph node endothelial cells for Gd-loaded hyaluronic acid-chitosan based nanogels with a concentration in chitosan of $2.5 \mathrm{mg} \cdot \mathrm{mL}^{-1}$.
\end{abstract}

Keywords: gadolinium; nanogels; SVEC4-10 cell line; cytotoxicity; oxidative stress; genotoxicity

\section{Introduction}

Magnetic resonance imaging (MRI) is a powerful non-invasive and non-ionizing tool for imaging tissues as well as tumours in humans and animals. It offers a high 3D spatial resolution and infinite tissue penetration [1] but suffers from poor sensitivity. In this context, complexes of paramagnetic metal ions, mostly lanthanides [2], iron oxide nanoparticles [3] as well as organic radical contrast agents [4] are used to improve the image contrast. Gadolinium-based contrast agents (GdCAs) are the most commonly used agents in clinical MRI [5] and have been used to enhance MRI sensitivity by enhancing the signal contrast between normal and tumour tissues [6,7]. To have a positive impact on the contrast, a high GdCA concentration must be injected, which-in some cases of kidney failure for example-may be problematic [8-10]. To overcome this drawback varied nanoplatforms 
integrating gadolinium chelates including lipid-based [11], polymeric [12] and silica NPs [13], as well as micelles [14], dendrimers [15] and nanogels [16] were synthesized. However, the biocompatibility and ultimately biodegradability of gadolinium-based imaging agents are crucial issues to consider since they are designed for in vivo administration [17]. For these reasons and due to their specific properties, such as hydrophilicity, biodegradability and biological activity, polysaccharides such as chitosan (CS) and hyaluronic acid (HA) are of great interest to design biocompatible polymeric nanoparticles $[18,19]$.

CS is currently used in biomedical field due to its biocompatibility and low-toxicity [20,21]. It is a linear positively charged polysaccharide composed of N-acetyl-D-glucosamine and D-glucosamine residues and obtained by partial deacetylation of chitin [22,23]. Among all other natural polymers, CS is the only one that has a cationic character. This behaviour is based on its primary amino groups which are ionized in weakly acidic media, allowing the biopolymer to adhere to the negatively charged surfaces and thus to the cell membrane [24]. The cationic character of chitosan is responsible for its special characteristics such as muco-adhesiveness [25], antitumor [26,27], antimicrobial [28], antioxidant activities [29] and ability to interfere with cellular tight junctions [30]. Consequently, it is used in the development of new drug delivery systems [12,25,31-38].

Hyaluronic acid (HA) is a linear anionic polymer, a free un-branched glycosaminoglycan constituted of D-glucuronic acid and $N$-acetyl-D-glucosamine residues. HA is naturally occurring mainly in the extracellular matrix and connective tissues of vertebrates [39]. Because of its cell surface receptors (CD44, RHAMM, HARE and LYVE-1) it is involved in several biological processes such as endocytosis, homeostasis and intracellular signalling transduction [40-42]. It is biodegradable, biocompatible, bioactive, non-inflammatory and non-cytotoxic [43] and due to these advantages, it is a widely investigated biomaterial in drug delivery [44,45], tissue engineering [42,46] and molecular imaging [47,48].

The applicability of CS is hindered by its solubility, which can be increased by modifications made to the free amino groups along the chitosan backbone under mild conditions. However, in the presence of specific polyanions, chitosan has the ability to form a novel class of hydrophilic biomaterial, called hydrogels.

Many studies were focused on synthesis of hydrogels by ionic gelation using HA [49-60]. Recently, hyaluronic acid-chitosan (HA-CS) based nanogels have become a promising strategy for confinement of GdCAs in designing of new MRI probes. [60-64].

Up to now, only a few studies regarding the biocompatibility of these nanoparticles have been reported. Zhang et al. have shown both the safety of gadolinium-loaded CS nanoparticles against B16 cells [65] and HA-CS nanoparticles against B16, HepG2 and A549 cells [64]. HA modified CS-gadolinium nanospheres generated a low cellular cytotoxicity towards HCT 116 cells [60]. Moon et al. evaluated the toxicity profile of HA-DTPA-Gd in two cell lines (NIH3T3 and FL83B) [47] and showed that compared to NIH3T3 cells, cytoxicity in FL83B was increased at higher dose of HA-DTPA-Gd applied. Previous studies also indicated that gadolinium complexes such as GdDOTA and GdDOTP encapsulated in a hydrophilic matrix constituted of CS and HA had no impact on C6 glioma cells and fibroblasts from rat skin viabilities [61,63], that suggested a high biocompatibility with these cell lines. Nevertheless, our group demonstrated that these nanogels could induce a slight oxidative stress towards A20 lymphocytes [66]. Since these nanogels are designed for lymphatic system imaging it is important to evaluate their in vitro effects towards dedicated cell lines, such as SVEC4-10 murine lymph node cells. A preliminary study conducted with this cell line [67] seemed to indicate that under certain conditions, results similar to those demonstrated for A20 lymphocytes were obtained. To have a better insight of the biological effects induced by Gd nanogels on SVEC4-10 murine lymph node cells, the impact towards these cells of CS-HA nanogels synthesized with two CS concentrations (1.5 and $2.5 \mathrm{mg} \cdot \mathrm{mL}^{-1}$ ) and two paramagnetic Gd chelates (GdDOTA and GdDOTP) was evaluated. In this respect, total cellular biomass, lactate dehydrogenase (LDH) activity, reactive oxygen species (ROS), lipid peroxidation, reduced glutathione (GSH), as well as the level of nuclear factor (erythroid-derived 2)-like 2 (Nrf-2) protein expression and the genotoxic effect by alkaline comet assay were analysed. 


\section{Materials and Methods}

\subsection{Reagents}

Sterile water was purchased from Laboratoire Aguettant, Lyon, France and sodium tripolyphosphate (TPP) from Acros Organics. DOTA and DOTP were purchased from Macrocyclics (Dallas, TX, USA). Chitosan (CS, low viscosity from shrimp shells) and sodium hyaluronate were provided by Sigma-Aldrich (St. Louis MO, USA) and bovine serum albumin by Sigma (Auckland, New Zealand). Fetal bovine serum, Dulbecco's Modified Eagle Medium (DMEM), phosphate-buffered saline (PBS) were purchased from Gibco (Grand Island, NY, USA) and WesternBreeze ${ }^{\circledR}$ Chromogenic Kits were procured from Invitrogen by Thermo Fisher Scientific Inc. (Waltham, MA, USA). In Vitro Toxicology Assay Kit Sulforhodamine B based, In Vitro Toxicology Assay Kit Lactic Dehydrogenase based, reduced glutathione (GSH), 5,5-dithio-bis-(2-nitrobenzoic acid), thiobarbituric acid (TBA); penicillin-streptomycin-amphotericin antibiotic mixture, $2^{\prime}, 7^{\prime}$-dichlorofluorescein diacetate (DCFH-DA) and 1,1,3,3-tetramethoxypropane were provided by Sigma (St. Louis, MO, USA). SVEC4-10 endothelial cell line was obtained from American Type Culture Collection (ATCC), Rockville, MD, USA. OxiSelect ${ }^{\mathrm{TM}}$ Comet Assay Kit (3-Well Slides) was purchased from Cell Biolabs, specific primary antibodies Nrf-2 from Santa Cruz Biotechnology, Inc. (Heidelberg, Germany) and all other chemicals used were of high purity and available from commercial suppliers.

\subsection{Synthesis and Characterization of Nanogels (NGs)}

Four stock solutions of chitosan were prepared by dissolution of the CS powder at concentrations of $2.5 \mathrm{mg} \cdot \mathrm{mL}^{-1}$ or $1.5 \mathrm{mg} \cdot \mathrm{mL}^{-1}$ in a $10 \%(\mathrm{~m} / \mathrm{v})$ citric acid or acetic acid aqueous solution and stirred overnight.

Nanogels were obtained by an ionotropic gelation process [61,63]. The polyanionic phase, that is, HA $\left(0.8 \mathrm{mg} \cdot \mathrm{mL}^{-1}\right)$ and TPP $\left(1.2 \mathrm{mg} \cdot \mathrm{mL}^{-1}\right)$ in water $(4.5 \mathrm{~mL})$, were added dropwise to the CS solution $(9 \mathrm{~mL})$ under sonication (750W, amplitude $32 \%$ ) to obtain stable nanosuspensions. The gadolinium complex (GdDOTP or GdDOTA) was previously dissolved in the polyanion solution. At the end of the addition, magnetic stirring was maintained for $10 \mathrm{~min}$. Unloaded nanogels were obtained in the same way, omitting the gadolinium complex. Nanosuspensions were then freeze-dried, using glucose $15 \%(\mathrm{~m} / \mathrm{v})$ as a cryoprotectant. Nanoparticle average hydrodynamic diameters $\left(\mathrm{D}_{\mathrm{H}}\right)$ and polydispersity indexes (PdI) were determined by Dynamic Light Scattering (DLS) (Malvern Zetasizer Nano-ZS, Malvern Instruments, Worcestershire, UK). Each nanosuspension was analysed in triplicate at $20{ }^{\circ} \mathrm{C}$ at a scattering angle of $173^{\circ}$, for each sample, after $1 / 20$ dilution in water. Pure water was used as a reference dispersing medium. $\zeta$-(zeta) potential data were collected through electrophoretic light scattering at $20^{\circ} \mathrm{C}, 150 \mathrm{~V}$, in triplicate for each sample, after $1 / 20$ dilution in water. The instrument was calibrated with a Malvern-68 mV standard before each analysis cycle.

The shape and the surface morphology of the nanogels were investigated by atomic force microscopy (AFM) (Catalyst, BrukerNano) in tapping mode. Samples were prepared by placing a drop of nanoparticle suspension on a freshly-cleaved mica sheet and the experiments were performed in fluid tapping mode to keep the integrity of the NPs. AFM images were generated with a scan rate of $1 \mathrm{~Hz}$ and 512 lines per image. Experiments were performed at constant room temperature. During the scans, proportional and integral gains were increased to the value just below the feedback started to oscillate. Images were processed only by flattening to remove background slopes.

Gadolinium nanogel loading was determined on nanoparticle suspensions by ICP-OES. The nanoparticle suspension was incubated overnight in a 1:3 $(v / v)$ mixture of $\mathrm{HCl}(37 \%)$ and $\mathrm{HNO}_{3}$ $(69 \%)$. Volumetric dilutions were carried out to achieve an appropriate Gd concentration within the working range of the method. Samples were analysed using Thermo Scientific iCAP 6300 series Duo ICP spectrometer. Gd emission intensity was correlated to Gd concentration by means of a calibration curve which was previously established from $\mathrm{Gd}\left(\mathrm{NO}_{3}\right)_{3} \mathrm{ICP}-\mathrm{OES}$ standard. Solutions used for the calibration were obtained by dilution of increasing amounts of $\mathrm{Gd}\left(\mathrm{NO}_{3}\right)_{3}$ standard with unloaded nanogels previously incubated under acidic conditions, as described above. 


\subsection{Cell Culture Conditions and Treatment}

Adherent murine SVEC4-10 cells (ATCC CRL 2181) were cultured in DMEM medium supplemented with $10 \%$ heat inactivated fetal bovine serum, $1 \%$ antibiotic-antimycotic mix and maintained at $37^{\circ} \mathrm{C}$ in a humidified air atmosphere with $5 \% \mathrm{CO}_{2}$ for specific time periods. The cells were seeded at a density of $5 \times 10^{4}$ cells $/ \mathrm{mL}$ into 24 well plates (for Sulforhodamine B and lactate dehydrogenase), $10^{5}$ cells $/ \mathrm{mL}$ in six well plates (for intracellular ROS) and in $25 \mathrm{~cm}^{2}$ culture flasks (for lipid peroxidation, glutathione reduced and Nrf-2 protein expression levels, as well as for comet assay). These were exposed to $1 \mu \mathrm{M}, 2.5 \mu \mathrm{M}, 5 \mu \mathrm{M}$ and $10 \mu \mathrm{M}$ of GdCACCS-TPP/HA nanogels $(\mathrm{GdCA}=$ GdDOTA or GdDOTP) for 6 and $24 \mathrm{~h}$. CS-TPP/HA nanogels were used as controls.

Before the treatment of cells, the stock solutions of nanogels with concentrations in range of 49-907 $\mu \mathrm{M}$ (presented in Table 1) were diluted in DMEM medium finally reaching the doses which were used for the cell incubations in biological experiments $(1,2.5,5$ and $10 \mu \mathrm{M} \mathrm{Gd})$.

\subsection{Preparation of Cell Lysate}

After each interval, cells were harvested from culture flasks using $0.25 \%$ trypsin solution and centrifuged at $1500 \mathrm{rpm}, 4{ }^{\circ} \mathrm{C}$ for $5 \mathrm{~min}$. Then, the cells were resuspended in $0.1 \mathrm{~mL}$ of PBS, sonicated (three times for $30 \mathrm{~s}$ on ice) using an Hielscher Ultrasonic processor UP50H and centrifuged at $5000 \mathrm{rpm}$, $4{ }^{\circ} \mathrm{C}$ for $10 \mathrm{~min}$. The supernatant was aliquoted and stored at $-80{ }^{\circ} \mathrm{C}$ and used for subsequent biochemical determinations. Protein concentration was measured according to Bradford method [68] using bovine serum albumin (BSA) as standard protein.

\subsection{Sulforhodamine B (SRB) Assay}

The cell viability was performed using a commercial kit (In Vitro Toxicology Assay Kit, Sulforhodamine B based, St. Louis MO, USA) according to manufacturer's instructions. This method is used for cell density determination, based on the measurement of total cellular biomass. After the treatment with GdCACCS-TPP/HA nanogels (GdCA = GdDOTA or GdDOTP) the cells were fixed for one hour at $4{ }^{\circ} \mathrm{C}$ with $50 \%$ TCA solution (1/4 volume of growth medium). Afterwards, cells were stained with $0.4 \%$ sulforhodamine B for $20 \mathrm{~min}$, then, rinsed quickly with $1 \%$ acetic acid. The incorporated dye was solubilized with $10 \mathrm{mM}$ Tris base solution. The absorbance was measured at $550 \mathrm{~nm}$ using a multireader (Thermo Scientific Appliskan, Vantaa, Finland) and the results were expressed relative to control cells.

\subsection{LDH Assay}

As a parameter of cytotoxicity in terms of cell membrane damage, LDH assay using the In Vitro Toxicology Assay Kit, Lactic Dehydrogenase based (Sigma-Aldrich, St. Louis, MO, USA), in accordance with the manufacturer's instructions, was performed [69]. The cells were seeded in 24 well plates and exposed at different concentrations of GdCA CCS-TPP/HA nanogels (GdCA = GdDOTA or GdDOTP) for 6 and $24 \mathrm{~h}$. Afterwards, a volume of $50 \mu \mathrm{L}$ of culture supernatant from each well was transferred to a new plate along with $100 \mu \mathrm{L}$ of LDH mix solution. After $30 \mathrm{~min}$ of incubation at room temperature, the reaction was stopped with $1 \mathrm{M} \mathrm{HCl}$. The absorbance was measured using a microplate reader (Thermo Scientific Appliskan) at $450 \mathrm{~nm}$ and the results were expressed relative to unloaded nanogels.

\subsection{Intracellular ROS Measurement}

Intracellular ROS generation was measured using $2^{\prime}, 7^{\prime}$-dichlorofluorescein diacetate (DCFH-DA) (Sigma-Aldrich, St. Louis, MO, USA). Briefly, a 10 mM DCFH-DA stock solution was diluted 1000-fold in free of serum cell culture medium to yield a $10 \mu \mathrm{M}$ working solution. After exposure of SVEC4-10 cells to $2.5 \mu \mathrm{M}$ and $10 \mu \mathrm{M}$ of GdCA CCS-TPP/HA nanogels (GdCA = GdDOTA or GdDOTP) for 6 and $24 \mathrm{~h}$, these were washed with PBS and incubated in a $2 \mathrm{~mL}$ working solution of $10 \mu \mathrm{M}$ DCFH-DA for $45 \mathrm{~min}$ at $37^{\circ} \mathrm{C}$ in the dark. Then, the cells were washed with PBS and resuspended in PBS for analysis. 
The intensity of DCF fluorescence was measured at an excitation and emission wavelengths of 485 and $530 \mathrm{~nm}$, respectively, using a FlexStation 3 Multi-Mode Microplate Reader from Molecular Devices LLC and the SoftMax Pro software. The fluorescence intensity was reported to the total number of viable cells and expressed as \% of unloaded CS-TPP/HA NGs.

\subsection{Lipid Peroxidation Measurement}

Determination of lipid peroxidation, one of the markers of lipids oxidative degradation was assessed using thiobarbituric acid (TBA). Malondialdehyde (MDA) was measured according to the method described by Del Rio et al. [70]. After 6 and 24 h exposure at GdCACCS-TPP/HA nanogels $(\mathrm{GdCA}=\mathrm{GdDOTA}$ or GdDOTP $)$, cells were collected and washed with PBS solution. Briefly, $200 \mu \mathrm{L}$ of cell suspension was mixed with $700 \mu \mathrm{L}$ of $0.1 \mathrm{M} \mathrm{HCl}$ and incubated at room temperature for $20 \mathrm{~min}$. After that, $900 \mu \mathrm{L}$ of $0.025 \mathrm{M}$ thiobarbituric acid were added and the mixture was maintained for $65 \mathrm{~min}$ at $37^{\circ} \mathrm{C}$. The MDA-TBA adduct was quantified fluorometrically $(\lambda \mathrm{exc} / \mathrm{em}=520 / 549 \mathrm{~nm})$ using a Jasco FP-750 spectrofluorometer (Tokyo, Japan). The results were expressed as nmoles of $\mathrm{MDA} / \mathrm{mg}$ of cellular protein and MDA concentration was calculated using a calibration curve with 1,1,3,3-tetramethoxy propane concentrations in the range of $0.5-5 \mu \mathrm{M}$.

\subsection{GSH Assay}

GSH concentrations were measured using the Glutathione Assay Kit from Sigma-Aldrich according to the manufacturer's instructions. After treatment, cell lysates were deproteinized with an equal volume of 5\% 5-sulfosalicylic acid (SSA) and centrifuged at 10,000 rpm, $4{ }^{\circ} \mathrm{C}$ for $10 \mathrm{~min}$. A volume of $10 \mu \mathrm{L}$ of each sample was placed in a 96-well microtiter plate and then, $150 \mu \mathrm{L}$ of working mixture were added. After $5 \mathrm{~min}$ incubation at room temperature, the absorbance was measured spectrophotometrically at a wavelength of $412 \mathrm{~nm}$ and the results were expressed in nmoles GSH/mg of protein.

\subsection{Western Blot Assay}

SVEC4-10 cells were exposed to $2.5 \mu \mathrm{M}$ and $10 \mu \mathrm{M}$ GdCA CCS-TPP/HA nanogels $(\mathrm{GdCA}=$ GdDOTA or GdDOTP) for 6 and 24 h. After exposure, cells were collected, washed with PBS and lysed using the Hielscher Ultrasonic processor UP50H. Protein concentration was determined using Bradford reagent and serum bovine albumin as standard. The protein samples (25 $\mu \mathrm{g})$ were resolved by $10 \%$ SDS gels at $90 \mathrm{~V}$ and transferred to polyvinylidene difluoride membranes (Merck KGaA, Darmstadt, Germany) at $350 \mathrm{~mA}$ for $90 \mathrm{~min}$ in a wet transfer system (Bio-Rad, Hercules, CA, USA). After blocking, membranes were incubated with dilute solution (1:250) of primary antibodies including Nrf-2 (Santa Cruz Biotechnology Inc., Heidelberg, Germany) and anti- $\beta$-actin (Sigma) overnight at $4{ }^{\circ} \mathrm{C}$. Then, membranes were incubated with anti-rabbit secondary antibodies coupled with alkaline phosphatase at room temperature for one hour. The protein bands were detected using BCIP/NBT as chromogenic substrate and visualized with the Bio-Rad ChemiDoc Imaging System (Bio-Rad, Hercules, CA, USA). Protein expression was quantified with Bio-Rad Image Lab software (version 5.2, Bio-Rad, Hercules, CA, USA), normalized to actin and the results were represented as percentage from controls.

\subsection{Comet Assay}

The Comet Assay, also known as single cell gel electrophoresis (SCGE), is a visual and sensitive technique for measuring DNA breakage in individual mammalian cells. After cells exposure to $2.5 \mu \mathrm{M}$ and $10 \mu \mathrm{M}$ of GdCACCS-TPP/HA (GdCA = GdDOTA or GdDOTP) NGs, DNA damage was analysed by Single cell gel electrophoresis kit (Cell Biolabs, INC). SVEC4-10 cells were harvested and re-suspended in ice-cold PBS at $1 \times 10^{5}$ cells $/ \mathrm{mL}$ density. A cell suspension of $8 \mu \mathrm{L}$ was mixed with $80 \mu \mathrm{L}$ of low melting agarose and then, $75 \mu \mathrm{L}$ were pipetted onto a comet-slide. The slides were maintained horizontally in dark at $4{ }^{\circ} \mathrm{C}$ for $15 \mathrm{~min}$, then, these were transferred in pre-chilled lysing solution at $4{ }^{\circ} \mathrm{C}$ for one hour. Afterwards, lysis solution was removed and slides were immersed in 
alkaline solution for $30 \mathrm{~min}$ at $4{ }^{\circ} \mathrm{C}$ in the dark. The slides were washed twice for 5 min with pre-chilled deionized water and then, these were electrophoresed in a horizontal chamber at low voltage $(300 \mathrm{~mA}$, $25 \mathrm{~V}$ ) for $30 \mathrm{~min}$. Following electrophoresis, the slides were immersed in $70 \%$ ethanol for $5 \mathrm{~min}$. The samples were allowed to air dry, stained with a Vista Green DNA dye for 15 min and visualized by epifluorescence microscopy (Olympus IX 71, Tokyo, Japan) using a fluorescein isothiocyanate (FITC) filter. Data were analysed using the Open Comet program. The percentage of DNA in tail was selected as indicator of DNA damage.

\subsection{Statistical Analysis}

Statistical analysis was performed using Student's $t$ test (Microsoft Excel) and all values were expressed as average $\pm \mathrm{SD}(n=3)$. A $p$ value $<0.05$ was considered statistically significant and data were represented as graphics relative to control which was considered $100 \%$. Each test was performed in three independent experiments.

\section{Results}

\subsection{Physico-Chemical Characteristics of GdDOTA and GdDOTP Based Nanogels}

GdCACCS-TPP/HA nanogels (GdCA = GdDOTA or GdDOTP) were prepared by a one-step ionotropic gelation process [61,63]. This method relied upon the establishment of multivalent electrostatic interactions between CS derivatives (polycationic) and HA (polyanionic). The resulting supramolecular network could be reinforced by cross-linking mediated by small anionic cross-linkers such as TPP. The average hydrodynamic diameters of GdCA $\subset$ CS-TPP/HA NGs were determined by DLS as well as the polydispersity index of the NP population (Table 1 ). Nanoparticle zeta potential $(\zeta)$ which was indicative of their outermost surface charge was determined by ELS.

Table 1. Nanogel characteristics and Gd(III) loadings of GdCACCS-TPP/HA nanogels (NGs) according to chitosan (CS) concentration in the acid (citric or acetic) phase.

\begin{tabular}{|c|c|c|c|c|}
\hline [CS] mg/mL & \multicolumn{4}{|c|}{2.5} \\
\hline GdCA & \multicolumn{2}{|c|}{ GdDOTP } & \multicolumn{2}{|c|}{ GdDOTA } \\
\hline Acid & Citric & Acetic & Citric & Acetic \\
\hline Entries & 1 & 2 & \multicolumn{2}{|c|}{ [67] } \\
\hline $\mathrm{D}_{\mathrm{H}}(\mathrm{nm})$ & 242 & 197 & 217 & 393 \\
\hline PdI & 0.2 & 0.4 & 0.2 & 0.4 \\
\hline$\zeta(\mathrm{mV})$ & 31.9 & 22.7 & 30.3 & 31.9 \\
\hline$[\mathrm{Gd}]_{\mathrm{t}} \mathrm{M}$ & $2.39 \times 10^{-4}$ & $7.82 \times 10^{-4}$ & $9.87 \times 10^{-5}$ & $9.07 \times 10^{-4}$ \\
\hline [CS] $\mathrm{mg} / \mathrm{mL}$ & \multicolumn{4}{|c|}{1.5} \\
\hline GdCA & \multicolumn{2}{|c|}{ GdDOTP } & \multicolumn{2}{|c|}{ GdDOTA } \\
\hline Acid & Citric & Acetic & Citric & Acetic \\
\hline Entries & 3 & 4 & 5 & 6 \\
\hline $\mathrm{D}_{\mathrm{H}}(\mathrm{nm})$ & 199 & 234 & 186 & 185 \\
\hline PdI & 0.2 & 0.3 & 0.2 & 0.3 \\
\hline$\zeta(\mathrm{mV})$ & 22.2 & 18.9 & 20.4 & 25.3 \\
\hline$[\mathrm{Gd}]_{\mathrm{t}} \mathrm{M}$ & $1.11 \times 10^{-4}$ & $3.30 \times 10^{-4}$ & $4.90 \times 10^{-5}$ & $2.64 \times 10^{-4}$ \\
\hline
\end{tabular}

For each CS concentration, nanogel mean sizes and their zeta potential were comparable, as well as the polydispersity indexes (PdI) of the corresponding nanosuspensions. Gd loadings were superior for formulations where CS concentration was $2.5 \mathrm{mg} \cdot \mathrm{mL}^{-1}$.

We have recently shown that in order to have a better insight in nanogel mean sizes, DLS data should be systematically consolidated by AFM observations in tapping mode [67]. Moreover, when AFM is performed in liquid mode, that is, in conditions close to the ones used in DLS, this technique is particularly well suited to image fragile samples such as hydrogels because friction and shear forces are negligible. By comparison to DLS, the advantage of AFM relies on the fact that it does not require the application of mathematical models to obtain size information. Therefore, AFM is more reliable 
to distinguish between individual nanoparticles and particle aggregates. By DLS, this is trickier and results in an overestimation of nanoparticle size [67]. AFM images were acquired in liquid mode for all the nanosuspensions (Figure 1).

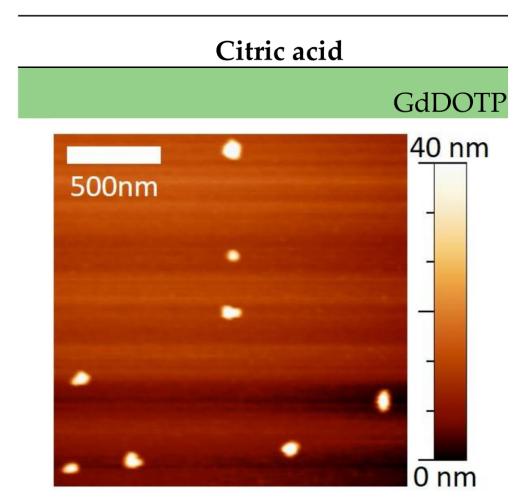

(a)

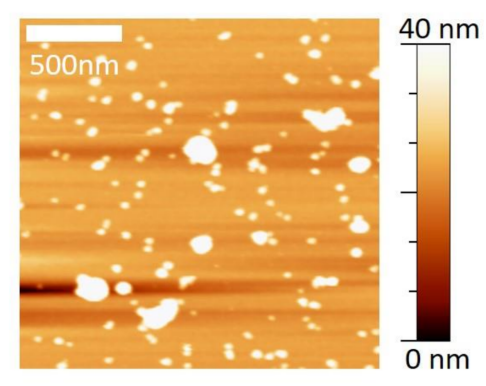

(c)

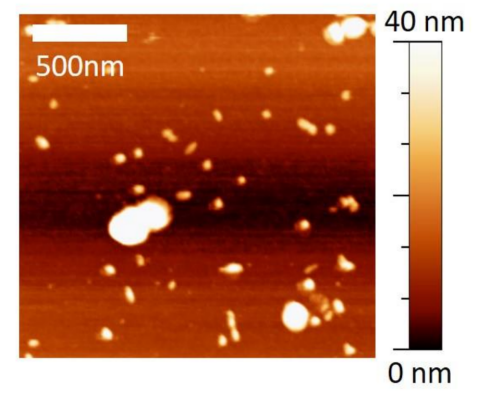

(d)

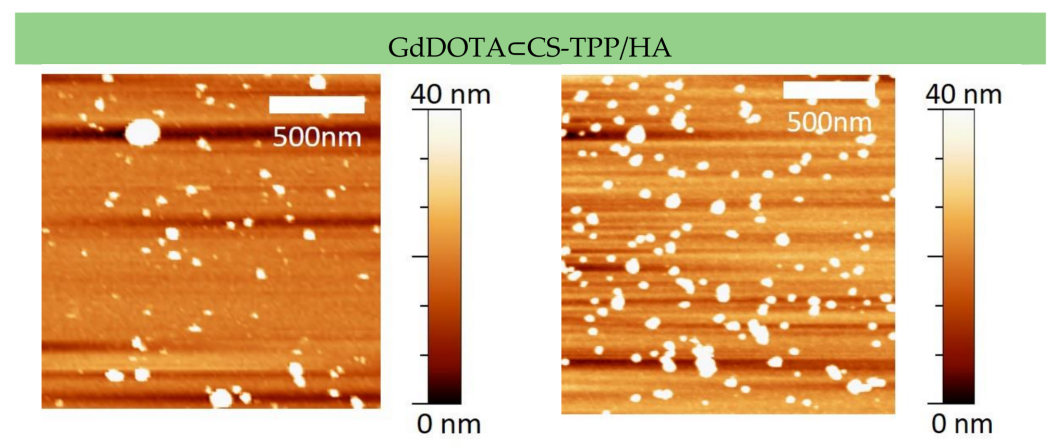

(e)

(f)

Figure 1. Atomic force microscopy (AFM) images in liquid of nanogels (a-f).

No topological differences could be noticed according to CS concentration, the acid or the gadolinium contrast agent. In any case, NGs diameters calculated from the AFM images were highly inferior to $100 \mathrm{~nm}$ (Table 2) as already demonstrated before [66].

Table 2. Nanogels 1 to 6 diameters ( $\left.\mathrm{d}_{\mathrm{AFM}}\right)$ in function of CS concentration and Gd contrast agent.

\begin{tabular}{ccccccc}
\hline Diameters & $\mathbf{1}$ & $\mathbf{2}$ & $\mathbf{3}$ & $\mathbf{4}$ & $\mathbf{5}$ & $\mathbf{6}$ \\
\hline $\mathrm{d}_{\mathrm{AFM}} \pm \mathrm{sd}(\mathrm{nm})$ & $69 \pm 8$ & $72 \pm 7$ & $53 \pm 6$ & $55 \pm 6$ & $51 \pm 10$ & $62 \pm 7$ \\
\hline \multicolumn{6}{c}{ CS concentration did not seem to have an impact on the particle diameters. }
\end{tabular}




\subsection{Effect of GdDOTA and GdDOTP Based Nanogels on Cell Viability}

A very important aspect in developing new nanogels for lymph node MRI is the evaluation of their toxicity when interacting with cells. In this study, the SVEC4-10 cells survival to increasing doses of GdCA CCS-TPP/HA NGs (GdCA = GdDOTA or GdDOTP) was tested after 6 and $24 \mathrm{~h}$ of exposure, using Sulforhodamine B viability test. First, we tested the viability of cells exposed to unloaded NGs compared to untreated cells. These results revealed the unloaded NGS were not toxic up to $24 \mathrm{~h}$ (Table 3).

Table 3. The viability of SVEC4-10 cells exposed to unloaded nanogels compared to untreated cells measured by SRB assay. Results are expressed relative to the untreated cells (100\%) and represented as average $\pm \operatorname{SD}(n=3)$.

\begin{tabular}{|c|c|c|c|c|c|}
\hline \multirow{3}{*}{ Time (h) } & \multirow{3}{*}{ Control (Untreated Cells) } & \multicolumn{4}{|c|}{ Unloaded CS-TPP/HA, $[\mathrm{CH}]_{\text {polycation phase }}\left(\mathrm{mg} \cdot \mathrm{mL}^{-1}\right)$} \\
\hline & & \multicolumn{2}{|c|}{2.5} & \multicolumn{2}{|c|}{1.5} \\
\hline & & Citric Acid & Acetic Acid & Citric Acid & Acetic Acid \\
\hline 6 & $100 \pm 2.05$ & $96.34 \pm 1.30$ & $100.00 \pm 3.70$ & $93.00 \pm 1.00$ & $92.00 \pm 3.31$ \\
\hline 24 & $100 \pm 2.4$ & $107.51 \pm 6.70$ & $103.55 \pm 4.80$ & $98.00 \pm 2.70$ & $103.86 \pm 1.91$ \\
\hline
\end{tabular}

Viabilities of Gd-NGs treated cells in percent of total cellular biomass of the control (cells treated with unloaded NGs) are displayed in Figure 2. No significant change in cell viability was registered at any concentrations applied up to $24 \mathrm{~h}$. It can be also observed that cell survival profiles are independent on the CS concentration and type nature of acid used for nanogel preparation and the gadolinium complex encapsulated. Cytotoxicity evaluated by SRB survival assay suggested that nanogels in doses up to $10 \mu \mathrm{M}$ were nontoxic and safe to this type of cell.

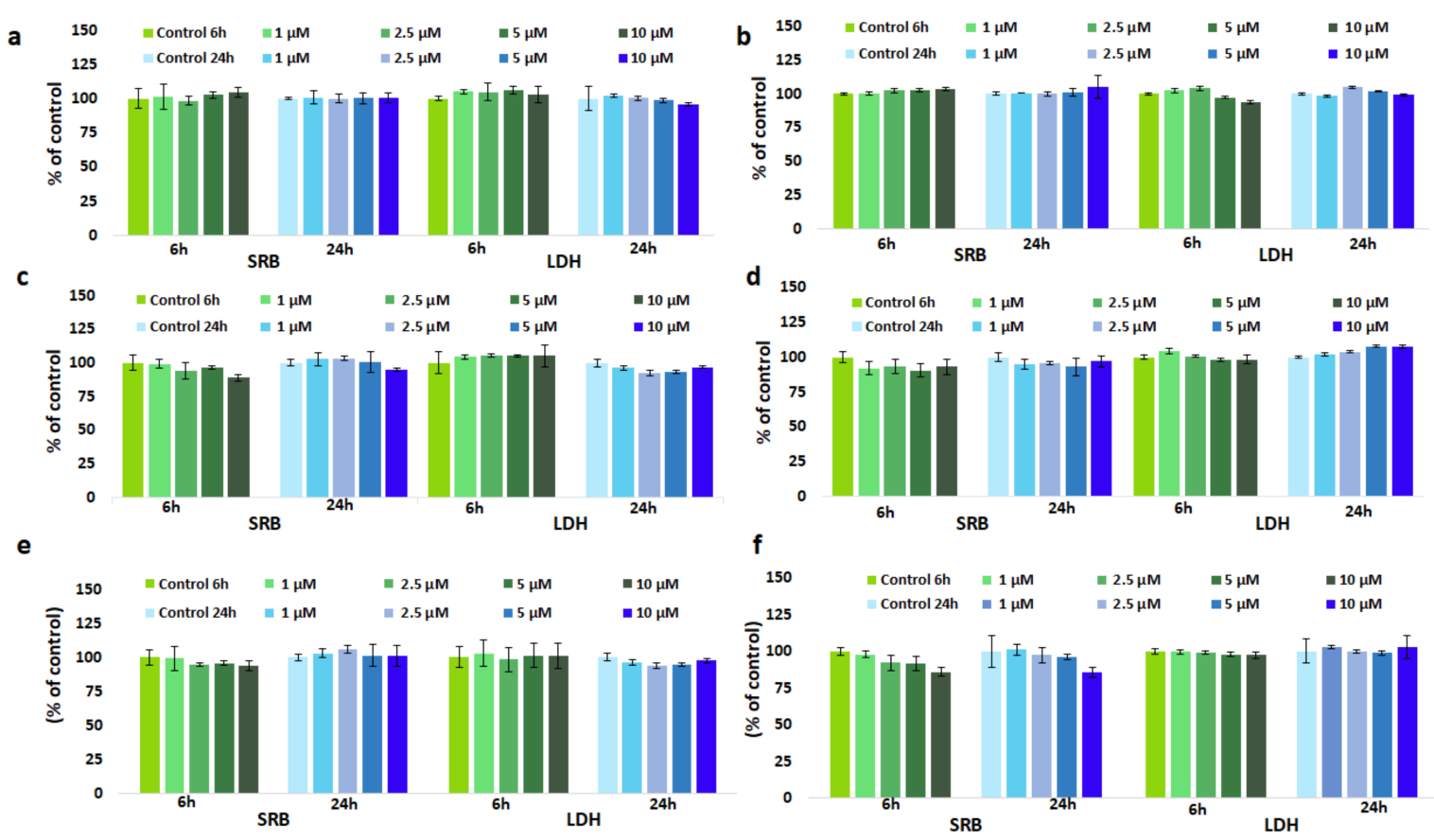

Figure 2. Viability and cytotoxicity evaluation in SVEC4-10 cells in the presence of increased concentrations of (a) GdDOTP citric acid, $2.5 \mathrm{mg} \cdot \mathrm{mL}^{-1} \mathrm{CS}$; (b) GdDOTP acetic acid, $2.5 \mathrm{mg} \cdot \mathrm{mL}^{-1} \mathrm{CS}$; (c) GdDOTP citric acid, $1.5 \mathrm{mg} \cdot \mathrm{mL}^{-1} \mathrm{CS}$; (d) GdDOTP acetic acid, $1.5 \mathrm{mg} \cdot \mathrm{mL}^{-1} \mathrm{CS}$; (e) GdDOTA citric acid, $1.5 \mathrm{mg} \cdot \mathrm{mL}^{-1} \mathrm{CS}$; (f) GdDOTA acetic acid, $1.5 \mathrm{mg} \cdot \mathrm{mL}^{-1} \mathrm{CS}$, after 6 and $24 \mathrm{~h}$. Unloaded CS-TPP/HA NGs obtained in citric and acetic acid were used as controls. Data are expressed as average $\pm \operatorname{SD}(n=3)$. 


\subsection{Effect of GdDOTA and GdDOTP Based Nanogels on Cell Membrane Integrity}

The effects of nanogels on SVEC 4-10 cells were investigated by assessing cellular membrane integrity through the LDH release. The cytotoxicity assay showed that, after 6 and $24 \mathrm{~h}$ of the incubation of SVEC4-10 cells with GdCACCS-TPP/HA NGs in doses ranging from 1 to $10 \mu \mathrm{M}$ no significant changes were noticed (Figure 2).

\subsection{Effect of GdDOTA and GdDOTP Based Nanogels on Oxidative Stress}

A significant increase of ROS level by 15\% and 20\% was observed in SVEC4-10 cells exposed to $10 \mu \mathrm{M}$ GdDOTA $\subset$ CS-TPP/HA NGs containing $1.5 \mathrm{mg} \cdot \mathrm{mL}^{-1} \mathrm{CS}$ (citric acid phase) (e), after 6 and $24 \mathrm{~h}$, respectively compared to control (CS-TPP/HA NGs). The fluorescence intensity of $2^{\prime}, 7^{\prime}$-dichlorodihydrofluorescein (DCF) was insignificant at the lower concentration $(2.5 \mu \mathrm{M})$, after 6 and $24 \mathrm{~h}$ (Figure 3). For the rest of nanogels no major ROS generation was noticed.

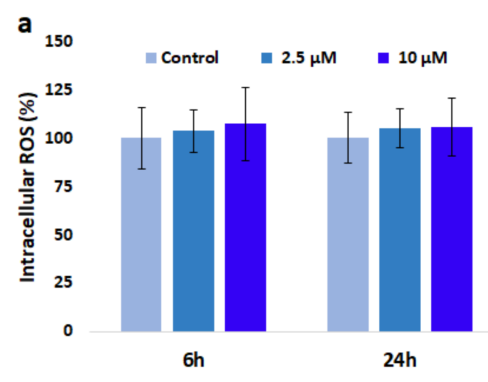

d

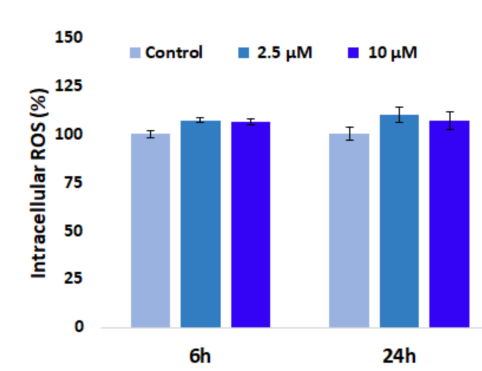

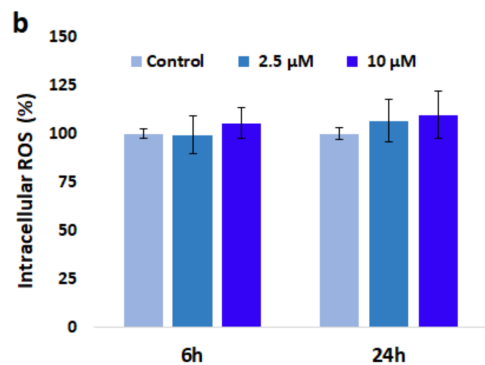

e

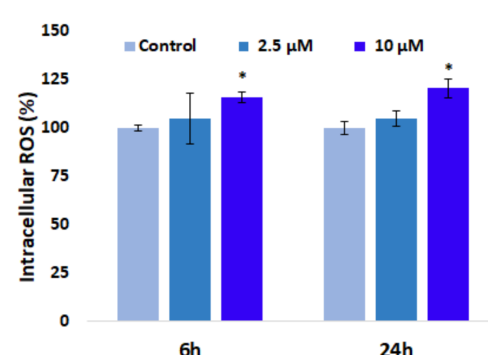

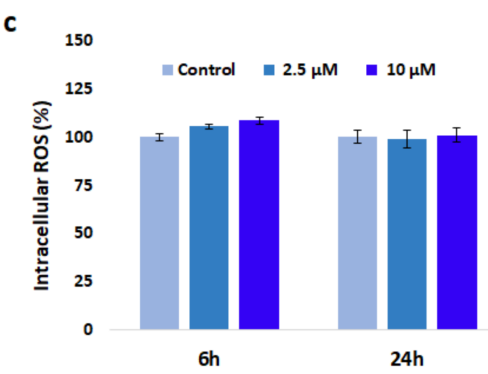

f

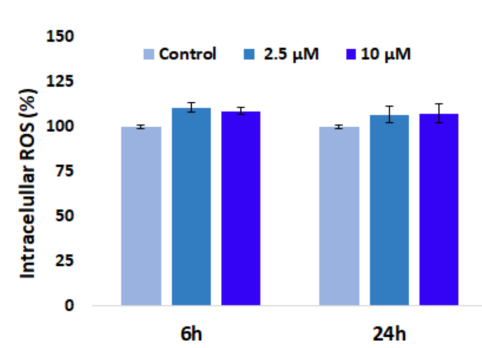

Figure 3. The intracellular reactive oxygen species (ROS) levels in SVEC4-10 cells in the presence of increased concentrations of (a) GdDOTP citric acid, $2.5 \mathrm{mg} \cdot \mathrm{mL}^{-1} \mathrm{CS}$; (b) GdDOTP acetic acid, $2.5 \mathrm{mg} \cdot \mathrm{mL}^{-1} \mathrm{CS}$; (c) GdDOTP citric acid, $1.5 \mathrm{mg} \cdot \mathrm{mL}^{-1} \mathrm{CS}$; (d) GdDOTP acetic acid, $1.5 \mathrm{mg} \cdot \mathrm{mL}^{-1} \mathrm{CS}$; (e) GdDOTA citric acid, $1.5 \mathrm{mg} \cdot \mathrm{mL}^{-1} \mathrm{CS}$; (f) GdDOTA acetic acid, $1.5 \mathrm{mg} \cdot \mathrm{mL}^{-1} \mathrm{CS}$, after 6 and $24 \mathrm{~h}$ Unloaded CS-TPP/HA NGs obtained in citric and acetic acid were used as controls. Data are expressed as average $\pm \operatorname{SD}(n=3)$.

\subsection{Effect of GdDOTA and GdDOTP Based Nanogels on Lipid Peroxidation}

Figure 4 shows the levels of MDA measured for SVEC4-10 cells, following their exposure to different GdCA $\subset$ CS-TPP/HA NGs for 6 and 24 h. For endothelial cells treated with both citric and acetic GdDOTP $\subset$ CS-TPP/HA ( $a$ and $b$ ) where CS concentration was $2.5 \mathrm{mg} \cdot \mathrm{mL}^{-1}$, no remarkable increase of MDA level was observed. By contrast, for NGs with $1.5 \mathrm{mg} \cdot \mathrm{mL}^{-1} \mathrm{CS}$, a time-dependent increase of the MDA level in endothelial cells was noticed with the most significant changes by $24 \%, 20 \%$ and $17 \%$ being observed after $24 \mathrm{~h}$ of exposure to citric GdDOTA $\subset$ CS-TPP/HA (e) and GdDOTP $\subset$ CS-TPP $/$ HA (c) and acetic GdDOTP $\subset$ CS-TPP/HA (d), respectively, as compared to unloaded ones (CS-TPP/HA NGs). It should be noticed that no modification of MDA level was observed for SVEC4-10 cells treated with acetic GdDOTA $\subset$ CS-TPP/HA (f) nanogels. 

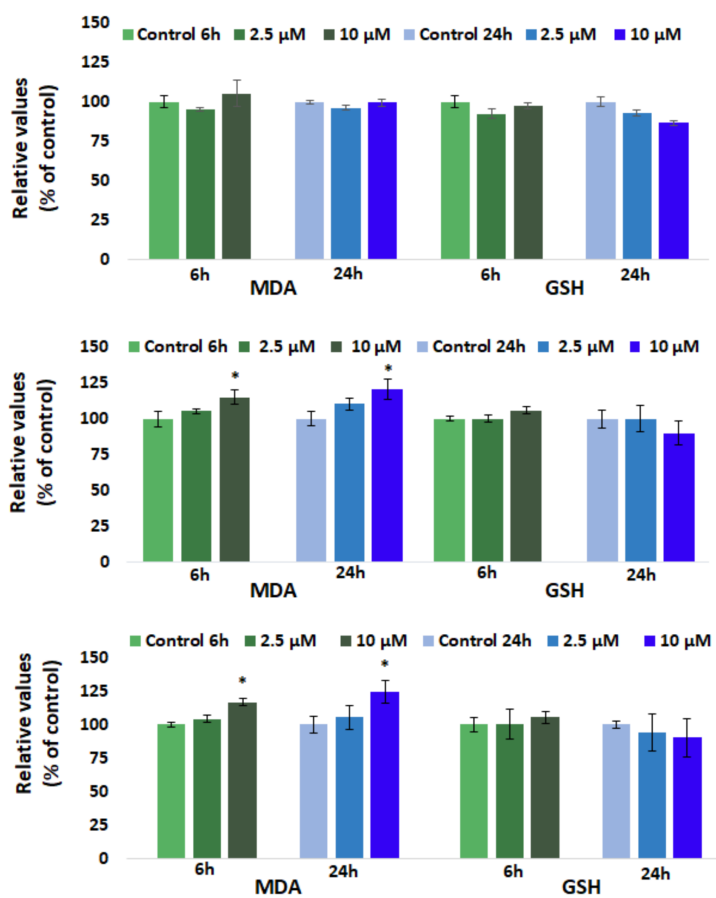

b
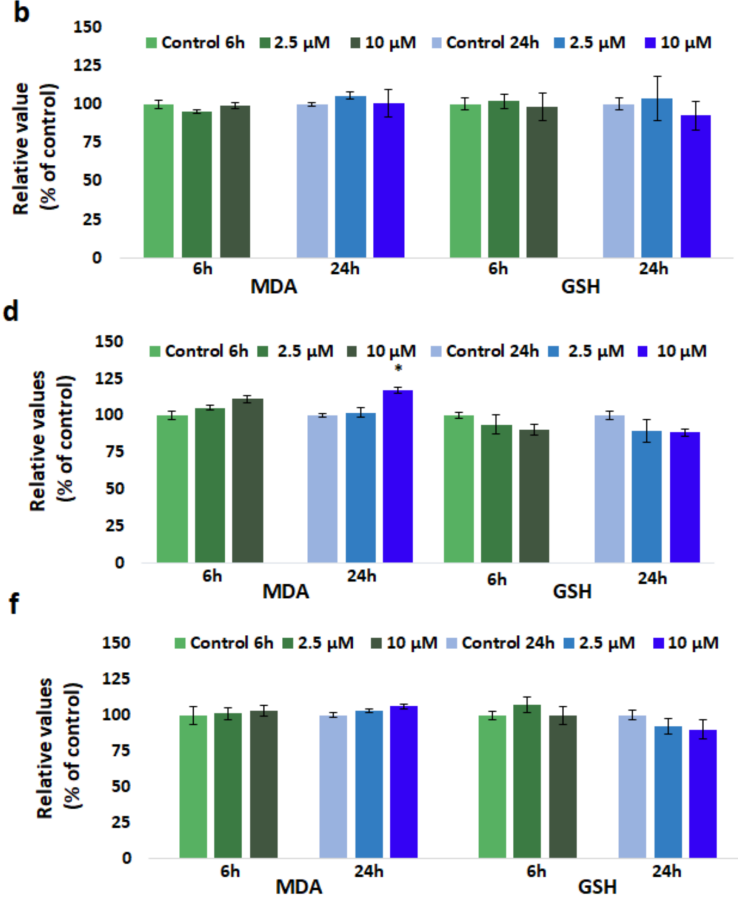

Figure 4. Malondialdehyde (MDA) and glutathione (GSH) relative levels in SVEC4-10 cells in the presence of increased concentrations of (a) GdDOTP citric acid, $2.5 \mathrm{mg} \cdot \mathrm{mL}^{-1} \mathrm{CS}$; (b) GdDOTP acetic acid, $2.5 \mathrm{mg} \cdot \mathrm{mL}^{-1} \mathrm{CS}$; (c) GdDOTP citric acid, $1.5 \mathrm{mg} \cdot \mathrm{mL}^{-1} \mathrm{CS}$; (d) GdDOTP acetic acid, $1.5 \mathrm{mg} \cdot \mathrm{mL}^{-1} \mathrm{CS}$; (e) GdDOTA citric acid, $1.5 \mathrm{mg} \cdot \mathrm{mL}^{-1} \mathrm{CS}$; (f) GdDOTA acetic acid, $1.5 \mathrm{mg} \cdot \mathrm{mL}^{-1} \mathrm{CS}$, after 6 and $24 \mathrm{~h}$. Unloaded CS-TPP/HA NPs obtained in citric and acetic acid were used as controls. Data are expressed as average $\pm \mathrm{SD}(n=3)$.

\subsection{Effect of GdDOTA and GdDOTP Based Nanogels on GSH Level}

No time- and dose-dependent reduction of GSH level was registered in SVEC4-10 cells treated with GdDOTP $\subset$ CS-TPP/HA ( $a$ and $b$ ) in both citric and acetic phase where CS concentration was $2.5 \mathrm{mg} \cdot \mathrm{mL}^{-1}$ (Figure 4) but slight decreases were observed when cells were treated for $24 \mathrm{~h}$ with $10 \mu \mathrm{M}$ GdCACCS-TPP/HA NGs with $1.5 \mathrm{mg} \cdot \mathrm{mL}^{-1} \mathrm{CS}$. In this case, GSH level was diminished by about $12 \%$ and $10 \%$ when cells were exposed to citric GdDOTA CCS-TPP/HA (e), GdDOTP $\subset$ CS-TPP/HA (c) and acetic GdDOTA $\subset C S-T P P / H A(f), G d D O T P \subset C S-T P P / H A(d)$, respectively, comparing to the corresponding controls (CS-TPP/HA NGs).

\subsection{Effect of GdDOTA and GdDOTP Based Nanogels on Nrf-2 Protein Expression}

The expression level of Nrf-2 was measured by Western blot analysis and the results are presented in Figure 5. Insignificant changes in Nrf-2 protein level between GdCACCS-TPP/HA NGs- and unloaded NGs-exposed cells were noticed during the entire analysed period. In addition, for nanogels synthesized under similar conditions (i.e., same acid and same $\mathrm{Gd}$ chelate) no differences were registered for both doses of CS. 
a
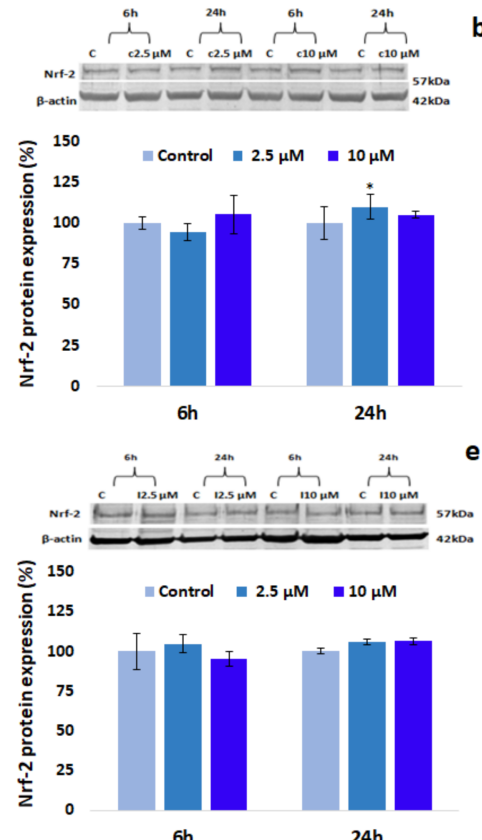

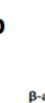

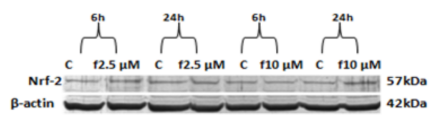

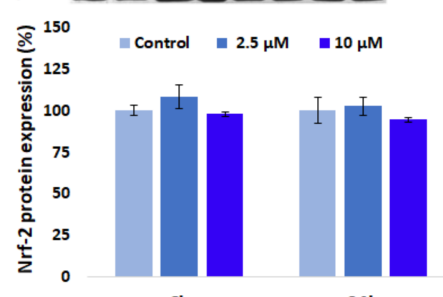

$6 \mathrm{~h}$

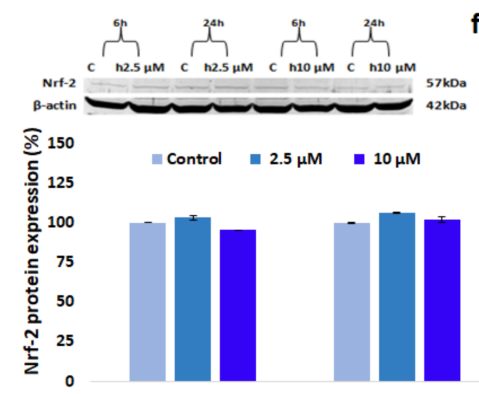

$6 \mathrm{~h}$

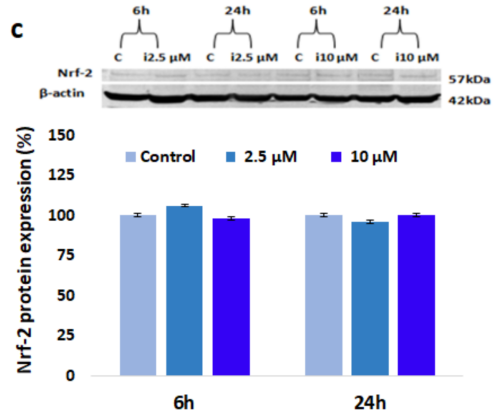

$6 \mathrm{~h}$

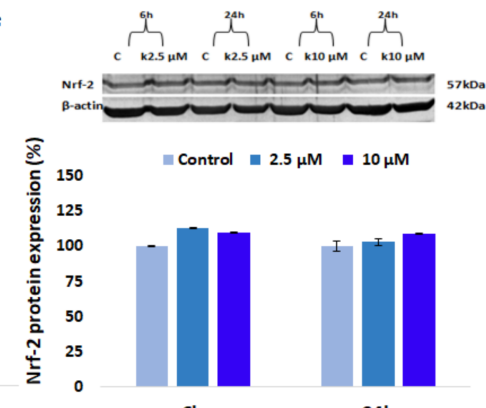

6h

$24 \mathrm{~h}$

Figure 5. Nrf-2 protein expression in SVEC4-10 cells in the presence of increased concentrations of (a) GdDOTP citric acid, $2.5 \mathrm{mg} \cdot \mathrm{mL}^{-1} \mathrm{CS}$; (b) GdDOTP acetic acid, $2.5 \mathrm{mg} \cdot \mathrm{mL}^{-1} \mathrm{CS}$; (c) GdDOTP citric acid, $1.5 \mathrm{mg} \cdot \mathrm{mL}^{-1} \mathrm{CS}$; (d) GdDOTP acetic acid, $1.5 \mathrm{mg} \cdot \mathrm{mL}^{-1} \mathrm{CS}$; (e) GdDOTA citric acid, $1.5 \mathrm{mg} \cdot \mathrm{mL}^{-1} \mathrm{CS}$; (f) GdDOTA acetic acid, $1.5 \mathrm{mg} \cdot \mathrm{mL}^{-1} \mathrm{CS}$, after 6 and $24 \mathrm{~h}$ Unloaded CS-TPP/HA NGs obtained in citric and acetic acid were used as controls. Data are expressed as average $\pm \operatorname{SD}(n=3)$.

\subsection{Genotoxic Effect of GdDOTA and GdDOTP Based Nanogels}

In order to check if nanogels can cause damage to nuclear DNA in SVEC4-10 cells, the alkaline Comet assay was performed (Figures 6 and 7). The results showed that nanosuspensions containing $2.5 \mathrm{mg} \cdot \mathrm{mL}^{-1} \mathrm{CS}$ did not induce formation of DNA strand breaks in SVEC4-10 cells even at higher dose applied for $24 \mathrm{~h}$. Furthermore, no significant difference was observed between cells treated with nanogels in citric phase and those treated with nanogels in acetic phase. In case of cells exposure to nanosuspensions containing $1.5 \mathrm{mg} \cdot \mathrm{mL}^{-1} \mathrm{CS}$, slight but significant changes were noticed. Thus, interaction of cells for 6 and $24 \mathrm{~h}$ with a higher concentration of citric GdDOTACCS-TPP/HA NGs (e) induced $10.3 \%$ and $9.1 \%$ DNA in the tail, compared to $8 \%$ and $6.5 \%$ for unloaded nanogels (CS-TPP/HA NGs). In addition, regardless of nanogels type and the applied dose, after $24 \mathrm{~h}$ a downward trend of DNA in tail was observed but without a statistical significance.
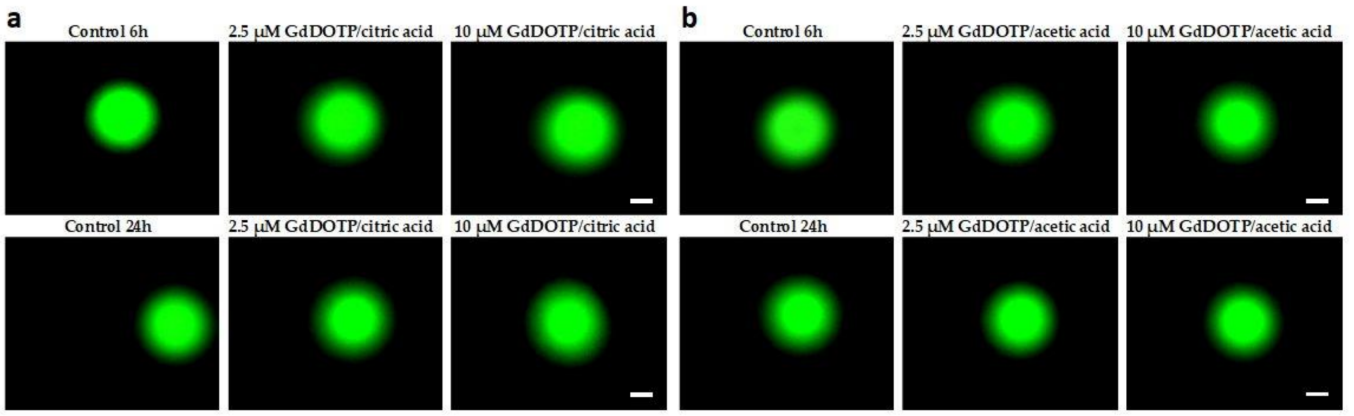

(A)

Figure 6. Cont. 


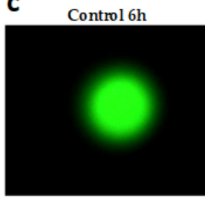

Control 24h

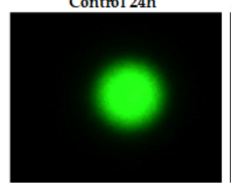

e Control $6 \mathrm{~h}$
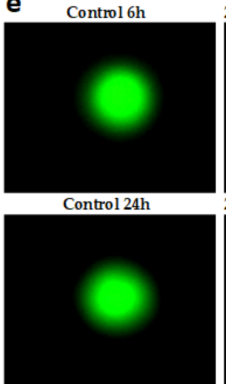
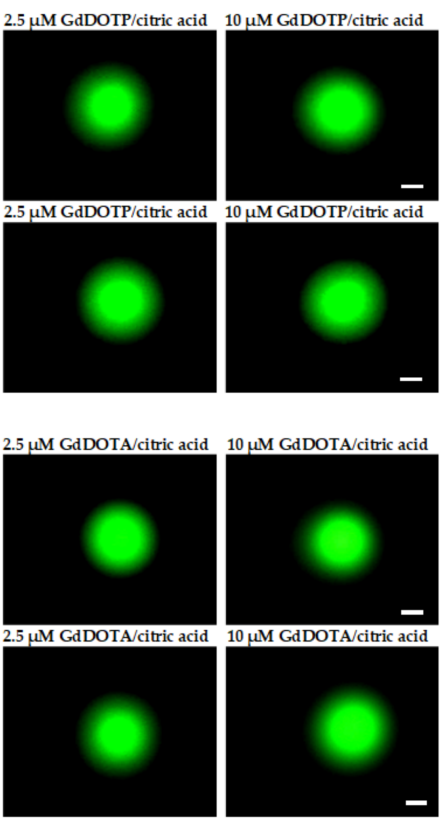

d
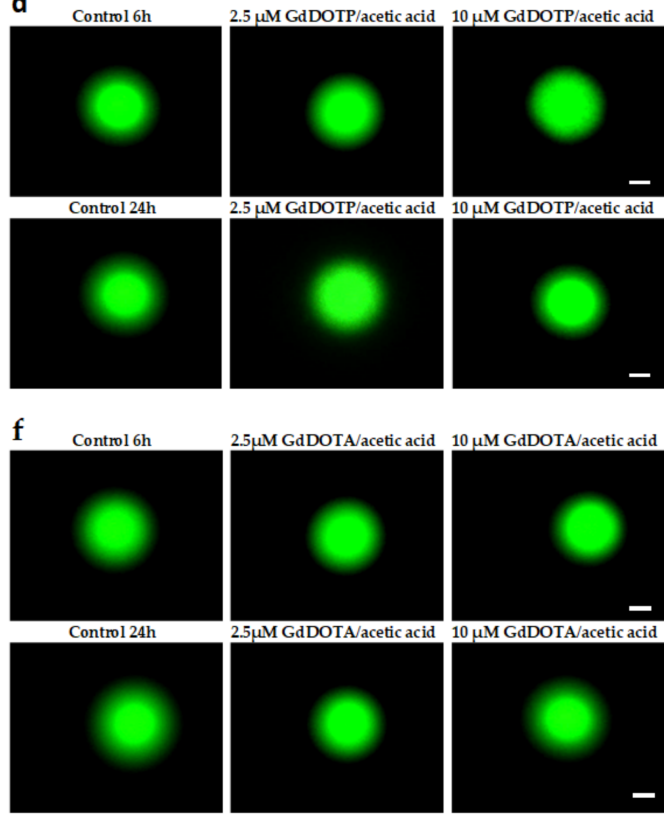

(B)

Figure 6. (A) Representative fluorescence images of SVEC4-10 cells in the presence of increased concentrations of (a) GdDOTP citric acid, $2.5 \mathrm{mg} \cdot \mathrm{mL}^{-1} \mathrm{CS}$; (b) GdDOTP acetic acid, $2.5 \mathrm{mg} \cdot \mathrm{mL}^{-1} \mathrm{CS}$ after 6 and $24 \mathrm{~h}$. Unloaded CS-TPP/HA NGs obtained in citric and acetic acid were used as controls. Scale bar $=50 \mu \mathrm{m}$. Magnification, $\times 100$. The green fluorescence intensity were analysed and quantified using the OpenComet program; (B) Representative fluorescence images of SVEC4-10 cells, in the presence of increased concentrations of, (c) GdDOTP citric acid, $1.5 \mathrm{mg} \cdot \mathrm{mL}^{-1} \mathrm{CS}$, (d) GdDOTP acetic acid, $1.5 \mathrm{mg} \cdot \mathrm{mL}^{-1} \mathrm{CS}$, (e) GdDOTA citric acid, $1.5 \mathrm{mg} \cdot \mathrm{mL}^{-1} \mathrm{CS}$, (f) GdDOTA acetic acid, $1.5 \mathrm{mg} \cdot \mathrm{mL}^{-1}$ CS after 6 and $24 \mathrm{~h}$. Unloaded CS-TPP/HA NGs obtained in citric and acetic acid were used as controls. Scale bar $=50 \mu \mathrm{m}$. The green fluorescence intensity were analysed and quantified using the OpenComet program. Magnification, $\times 100$.

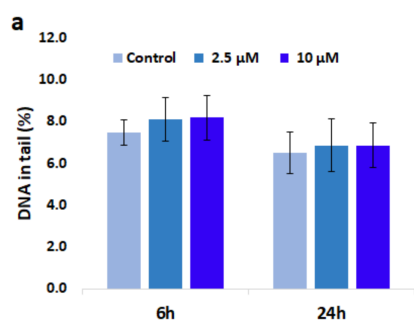

d

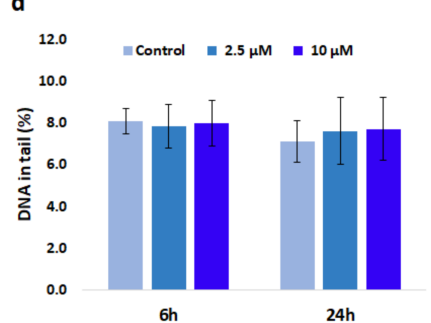

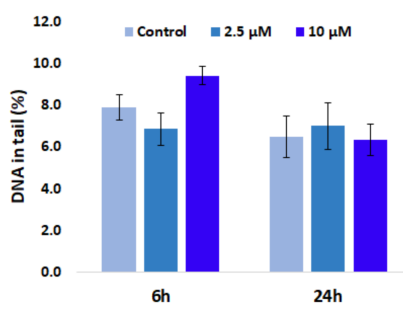

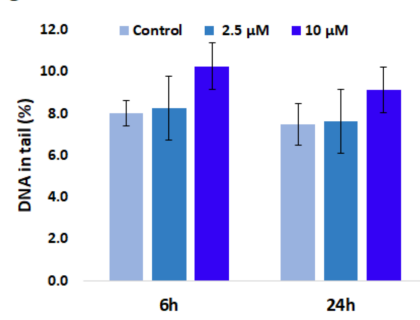

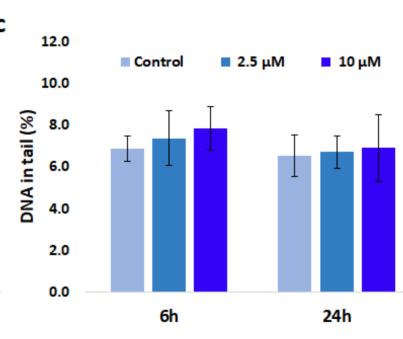

f

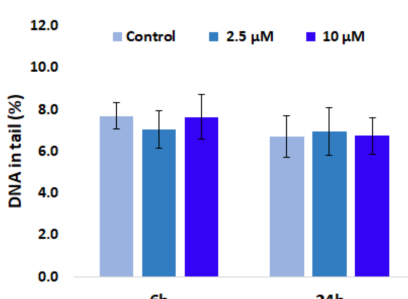

$24 \mathrm{~h}$

Figure 7. Genotoxicity response of SVEC4-10 cells exposed to different concentrations of (a) GdDOTP citric acid, $2.5 \mathrm{mg} \cdot \mathrm{mL}^{-1} \mathrm{CS}$; (b) GdDOTP acetic acid, $2.5 \mathrm{mg} \cdot \mathrm{mL}^{-1} \mathrm{CS}$; (c) GdDOTP citric acid, $1.5 \mathrm{mg} \cdot \mathrm{mL}^{-1} \mathrm{CS}$; (d) GdDOTP acetic acid, $1.5 \mathrm{mg} \cdot \mathrm{mL}^{-1} \mathrm{CS}$; (e) GdDOTA citric acid, $1.5 \mathrm{mg} \cdot \mathrm{mL}^{-1} \mathrm{CS}$; (f) GdDOTA acetic acid, $1.5 \mathrm{mg} \cdot \mathrm{mL}^{-1} \mathrm{CS}$, after 6 and $24 \mathrm{~h}$. Unloaded CS-TPP/HA NPs obtained in citric and acetic acid were used as controls. Data are expressed as average $\pm \operatorname{SD}(n=3)$. 


\section{Discussion}

The high potential of Gd-based nanogels in developing of new nanocarriers for theranostic applications have made these nanoparticles to be of great scientific interest for biomedical research in the last years. Taking into account that they are designed for in vivo imaging of lymphatic nodes and administrated by subcutaneous injection, biocompatibility of Gd-based nanogels is a critical issue that needs to be considered.

GdCACCS-TPP/HA nanogels (GdCA = GdDOTA or GdDOTP) were prepared by a one-step ionotropic gelation process $[61,63]$. This method relies upon the establishment of multivalent electrostatic interactions between CS derivatives (polycationic) and HA (polyanionic). The resulting supramolecular network can be reinforced by cross-linking mediated by small anionic cross-linkers such as TPP. For each CS concentration, nanogel mean sizes and their zeta potential were comparable, as well as the polydispersity indexes (PdI) of the corresponding nanosuspensions.

We have recently shown that in order to have a better insight in nanogel mean sizes, DLS data should be systematically consolidated by AFM observations in liquid mode [67]. Indeed, AFM is particularly well suited since this technique requires not only experimental conditions that are not invasive for nanogels but also no application of mathematical models to obtain size information. No topological differences could be noticed according to CS concentration, the acid or the gadolinium contrast agent. In any case, nanogels (NGs) diameters calculated from the AFM images were highly inferior to $100 \mathrm{~nm}$ (Table 2) as already demonstrated before [67].

$\mathrm{Gd}$ loadings were superior for formulations where CS concentration was $2.5 \mathrm{mg} \cdot \mathrm{mL}^{-1}$. This could be interpreted considering that the higher the concentration of CS, the denser the network of the nanogel and the more abundant the $\mathrm{CS} \mathrm{NH}_{3}{ }^{+}$groups. As a result, electrostatic interactions with anionic gadolinium chelates (GdDOTP ${ }^{5-}$ and $\mathrm{GdDOTA}^{-}$respectively) were promoted, resulting in higher concentrations of contrast agent.

Regarding the biological impact of nanogels on SVEC4-10 murine lymph node endothelial cells, no significant difference in cell survival profiles were noticed in our experiments according to CS concentration, type of acid or gadolinium contrast agent. These results are in agreement with two other cytotoxicity studies regarding exposure of Gd-based nanogels, to C6 glioma cells [61] and fibroblasts from rat skin cells [63].

A previous study on A20 cells viability [66] revealed that, while GdDOTA-NGs had no significant effect on cell survival profiles up to $24 \mathrm{~h}$, GdDOTP-NGs generated a decrease of cell viability in a time- and dose-dependent manner. A20 cell line seemed to be more susceptible to Gd-based nanogels treatment compared with SVEC4-10 endothelial cell line used in the current work. A cell-type-dependence of chitosan cytotoxic effects was reported by Wimardani et al. [71]. Regardless of CS concentration, Gd-based NGs type and exposure time, LDH release in the culture medium also revealed that Gd-loaded hyaluronic acid-chitosan-based nanogels caused no membrane destabilization and had no impact on cell homeostasis, confirmed also by SRB assay results.

In the present work, both cell viability and LDH release studies suggested the safety of these nanogels for SVEC4-10 murine lymph node endothelial cells, that are in accordance with biocompatibility and low-toxicity of CS [21] and HA [43]. Furthermore, our findings are in line with those generated by Baharifar et al., showing CS concentration as the main factor in determining cell viability [72]. Thus, maximum levels of CS concentration applied $\left(2.0 \mathrm{mg} \cdot \mathrm{mL}^{-1}\right)$ induced minimum toxicity of nanoparticles in MRC-5 cells.

Because not all defects in membrane or metabolic function are generated by disruptive effects, in order to determine the sub-lethal effects of nanoparticles, more extensive in vitro toxicity studies, such as oxidative stress were necessary [73].

Generation of reactive oxygen species (ROS) leading to oxidative stress was frequently associated with nanoparticles toxicity [74]. The antioxidant system plays a crucial role in maintaining cellular homeostasis. Under normal conditions, cells have the ability to maintain the equilibrium between generation and elimination of ROS. When production of ROS increases or ROS-scavenging capacity 
decreases, alterations in cellular redox status could occur leading to oxidative stress [75]. The cell antioxidant defence system can regulate the excess of ROS response under physiologic conditions and also protect against toxic agents. This defence system includes antioxidant enzymes and low molecular weight free-radical scavengers. The major non-enzymatic cellular antioxidant is glutathione (GSH), a tripeptide whose antioxidant function is provided by the sulfhydryl group of cysteine.

Previously, we have reported increases in ROS levels in a time dependent manner as well as reductions of GSH concentrations [66]. The present study showed a low and insignificant decrease of GSH level after exposure for $24 \mathrm{~h}$ at the highest dose of citric GdDOTACCS-TPP/HA (e) nanogel with $1.5 \mathrm{mg} \cdot \mathrm{mL}^{-1} \mathrm{CS}$.

For SVEC4-10 cells treated with GdDOTP $\subset$ CS-TPP/HA ( $a$ and $b$ ) in both citric and acetic phase with CS concentration of $2.5 \mathrm{mg} \cdot \mathrm{mL}^{-1}$ no GSH depletion and ROS generation were induced.

Due to its essential role in cell survival involving the regulatory effect on glutathione synthesis, Nrf-2 transcription factor (NF-E2 p45-related factor) is widely recognized as the master regulator of cellular redox homeostasis [76]. It is well known that, in cells where ROS levels are higher and GSH concentrations are lower, Nrf-2 disruption occurs.

The insignificant changes in Nrf-2 protein activity between Gd-loaded and unloaded-NGs exposed cells noticed during our experiments could be explained by the fact that, due to their antioxidant equipment, endothelial cells have the ability to handle the mild ROS stress generated.

Under oxidative stress, ROS attack the major classes of biological molecules, such as lipids proteins and DNA, leading oxidative damage [77]. Exposure to ROS causes a chain-reaction process in biological systems that induces firstly lipid peroxidation.

As an important marker of lipid peroxidation, a time-dependent increase of MDA levels was observed for nanogels with a CS concentration of $1.5 \mathrm{mg} \cdot \mathrm{mL}^{-1}$ compared to those with of $2.5 \mathrm{mg} \cdot \mathrm{mL}^{-1}$. The most significant changes of MDA levels by $24 \%, 20 \%$ and $17 \%$ after $24 \mathrm{~h}$ of exposure to citric GdDOTA $\subset$ CS-TPP/HA (e) and GdDOTP $\subset$ CS-TPP/HA (c) and acetic GdDOTP $\subset$ CS-TPP/HA (d) respectively, relative to unloaded ones, could suggest that cell antioxidant defence system was able to counteract the oxidative stress induced. On the other hand, these results may be at least partly explained by the susceptibility of polyunsaturated fatty acids of lipids to oxidative modification compared to other macromolecules (e.g., nuclear DNA) [75].

Upon cellular stress conditions, multiple genotoxic responses could be generated, one of them being DNA breakage.

Nanosuspensions containing $2.5 \mathrm{mg} \cdot \mathrm{mL}^{-1}$ CS did not elicit a genotoxic effect on SVEC4-10 cells at any dose tested and for both genotoxicity endpoints considered. Furthermore, irrespectively to the nanogels types and applied dose, the longer treatment time resulted in a downward trend of DNA strand breaks compared to the $6 \mathrm{~h}$ treatment. This could be due to the DNA repair processes, involved in the case of sub-lethal effects in order to ensure survival of cells [77].

On the other hand, the better results for DNA damage than those for lipid peroxidation could be explained by the fact that, due to its double helix structure, nuclear DNA is less vulnerable to oxidative modifications, compared to lipids [75].

Taking into account all these results, Gd-loaded hyaluronic acid-chitosan based nanogels with CS concentration of $2.5 \mathrm{mg} \cdot \mathrm{mL}^{-1}$ generated lower oxidative stress compared to those with CS concentration of $1.5 \mathrm{mg} \cdot \mathrm{mL}^{-1}$. Probably, this might be due to the chitosan free radical scavenger activity [78] that increases in a concentration-dependent manner [79] and to the protective effect of HA against oxidative stress [80,81].

\section{Conclusions}

In summary, the present study indicates that interaction of Gd-loaded hyaluronic acid-chitosan based nanogels in the dose range of 1-10 $\mu \mathrm{M}$ with SVEC4-10 cells occurred without affecting the viability and membrane integrity, even after $24 \mathrm{~h}$. The cells survival profiles seemed to be independent on the chitosan concentration. As a result of significant ROS generation, a low but insignificantly 
decrease of GSH concentration and a time-dependent increase of MDA level were produced by citric GdDOTACCS-TPP/HA nanogel with chitosan concentration of $1.5 \mathrm{mg} \cdot \mathrm{mL}^{-1}$, especially at the highest dose applied. The insignificant differences in Nrf-2 protein expression between Gd-loaded NGs-exposed cells and the relevant controls suggested that an oxidative stress was slightly induced but this point affected neither redox homeostasis nor cell survival.

Therefore, due to their good biocompatibility with lymph node endothelial cells, Gd-loaded hyaluronic acid-chitosan based nanogels with a concentration in chitosan of $2.5 \mathrm{mg} \cdot \mathrm{mL}^{-1}$ appears to be better candidates for future MRI lymph node studies.

Acknowledgments: The work was supported by ANR (Gadolymph project $n^{\circ}$ ANR-13-ENM2-0001-01, through the EuroNanoMed 2013 framework) and by the Romanian National Authority for Scientific Research CCCDI-UEFISCDI (project number 4-006/2014, EuroNanoMed II), by the Region Champagne Ardenne, the DRRT Champagne Ardenne (through MESR) and the EU-program FEDER (Project NanoBio2, Nano'Mat Platform). Amandine Destrebecq is thanked for her help with ICP-OES titrations.

Author Contributions: Cecilia Virginia Gheran and Sorina Nicoleta Voicu performed the biochemical experiments, analysed the data and wrote the draft of manuscript; Guillaume Rigaux and Maité Callewaert handled the synthesis and characterization of nanogels, analysed the data; Alexandre Berquand and Michael Molinari performed AFM images; Françoise Chuburu designed the study and wrote the synthesis of nanogels and Anca Dinischiotu designed the study and proofread the manuscript.

Conflicts of Interest: The authors declare no conflict of interest.

Compliance with Ethical Standards: The manuscript does not contain clinical studies or patient data.

\section{References}

1. Caravan, P. Strategies for increasing the sensitivity gadolinium based MRI contrast agents. Chem. Soc. Rev. 2006, 35, 512-523. [CrossRef] [PubMed]

2. Bonnet, C.S.; Tóth, É. Smart Contrat Agents for Magnetic Resonance Imaging. Chimia 2016, 70, $102-108$. [CrossRef] [PubMed]

3. Shen, Z.; Wu, A.; Chen, X. Iron Oxide Nanoparticle Based Contrast Agents for Magnetic Resonance Imaging. Mol. Pharm. 2017, 14, 1352-1364. [CrossRef] [PubMed]

4. Rajca, A.; Wang, Y.; Boska, M.; Paletta, J.T.; Olankitwanit, A.; Swanson, M.A.; Mitchell, D.G.; Eaton, S.S.; Eaton, G.R.; Rajca, S. Organic Radical Contrast Agents for Magnetic Resonance Imaging. J. Am. Chem. Soc. 2012, 134, 15724-15727. [CrossRef] [PubMed]

5. Zhou, Z.; Lu, Z.R. Gadolinium Based Contrast Agents for MR Cancer Imaging. Wiley Interdiscip Rev. Nanomed. Nanobiotechnol. 2013, 5, 1-18. [CrossRef] [PubMed]

6. Merbach, A.E.; Helm, L.; Tóth, É. The Chemistry of Contrast Agents in Medical Magnetic Resonance Imaging, 2nd ed.; Merbach, A.E., Helm, L., Tóth, É., Eds.; John Wiley \& Sons, Ltd.: Chichester, UK, 2013; pp. 1-152, ISBN 978-1-119-99176-2.

7. Terreno, E.; Castelli, D.D.; Viale, A.; Aime, S. Challenges for molecular magnetic resonance imaging. Chem. Rev. 2010, 110, 3019-3042. [CrossRef] [PubMed]

8. Idée, J.M.; Port, M.; Medina, C.; Lancelot, E.; Fayoux, E.; Ballet, S.; Corot, C. Possible involvement of gadolinium chelates in the pathophysiology of nephrogenic systemic fibrosis: A critical review. Toxicology 2008, 248, 77-88. [CrossRef] [PubMed]

9. Bertin, A.; Michou-Gallani, A.I.; Gallani, J.L.; Felder-Flesch, D. In vitro neurotoxicity of magnetic resonance imaging (MRI) contrast agents: Influence of the molecular structure and paramagnetic ion. Toxicol. In Vitro 2010, 24, 1386-1394. [CrossRef] [PubMed]

10. Kim, K.S.; Park, W.; Hu, J.; Bae, Y.H.; Na, K. A cancer-recognizable MRI contrast agents using pH-responsive polymeric micelle. Biomaterials 2014, 35, 337-343. [CrossRef] [PubMed]

11. Botta, M.; Tei, L. Relaxivity Enhancement in Macromolecular and Nanosized Gd ${ }^{\mathrm{III}}$-Based MRI Contrast Agents. Eur. J. Inorg. Chem. 2012, 12, 1945-1960. [CrossRef]

12. Darras, V.; Nelea, M.; Winnik, F.M.; Buschmann, M.D. Chitosan modified with gadolinium diethylenetriaminepentaacetic acid for magnetic resonance imaging of DNA/chitosan nanoparticles. Carbohydr. Polym. 2010, 80, 1137-1146. [CrossRef] 
13. Wartenberg, N.; Fries, P.; Raccurt, O.; Guillermo, A.; Imbert, D.; Mazzanti, M.A. Gadolinium Complex Confined in Silica Nanoparticles as a Highly Efficient T1/T2 MRI Contrast Agent. Chem. Eur. J. 2013, 19, 6980-6983. [CrossRef] [PubMed]

14. Shiraishi, K.; Kawano, K.; Maitani, Y.; Yokoyama, M. Polyion complex micelle MRI contrast agents from poly (ethylene glycol)-B-poly(L-lysine) block copolymers having Gd-DOTA; preparations and their control of T1-relaxivities and blood circulation characteristics. J. Control. Release 2010, 148, 160-167. [CrossRef] [PubMed]

15. Kesharwani, P.; Jain, K.; Jain, N.K. Dendrimer as nanocarrier for drug delivery. Prog. Polym. Sci. 2014, 39, 268-307. [CrossRef]

16. Lux, J.; Chan, M.; Vander Elst, L.; Schopf, E.; Mahmoud, E.; Laurent, S.; Almutairi, A. Metal Chelating Crosslinkers Form Nanogels with High Chelation Stability. J. Mater. Chem. B Mater. Biol. Med. 2013, 1, 6359-6364. [CrossRef] [PubMed]

17. Medina, C.; Santos-Martinez, M.J.; Radomski, A.; Corrigan, O.I.; Radomski, M.W. Nanoparticles: Pharmacological and toxicological significance. Br. J. Pharmacol. 2007, 150, 552-558. [CrossRef] [PubMed]

18. Rinaudo, M. Main properties and current applications of some polysaccharides as biomaterials. Polym. Int. 2008, 57, 397-430. [CrossRef]

19. Liu, Z.; Jiao, Y.; Wang, Y.; Zhou, C.; Zhang, Z. Polysaccharides-based nanoparticles as drug delivery systems. Adv. Drug Deliv. Rev. 2008, 60, 1650-1662. [CrossRef] [PubMed]

20. Kumar, M.N.; Muzzarelli, R.A.; Muzzarelli, C.; Sashiwa, H.; Domb, A.J. Chitosan chemistry and pharmaceutical perspectives. Chem. Rev. 2004, 104, 6017-6084. [CrossRef] [PubMed]

21. Kean, T.; Thanou, M. Biodegradation, biodistribution and toxicity of chitosan. Adv. Drug Deliv. Rev. 2010, 62, 3-11. [CrossRef] [PubMed]

22. Kean, T.; Thanou, M. Chitin and Chitosan: Sources, Production and Medical Applications. In Renewable Resources for Functional Polymers and Biomaterials: Polysaccharides, Proteins and Polyesters, 2nd ed.; RSC in Polymer Chemistry Series No. 1; Williams, P.A., Ed.; Royal Society of Chemistry: Cambridge, UK, 2011; pp. 292-318, ISBN 978-1-84973-351-9.

23. Younes, I.; Rinaudo, M. Chitin and Chitosan Preparation from Marine Sources. Structure, Properties and Applications. Mar. Drugs 2015, 13, 1133-1174. [CrossRef] [PubMed]

24. Gan, Q.; Wang, T.; Cochrane, C.; McCarron, P. Modulation of surface charge, particle size and morphological properties of chitosan-TPP nanoparticles intended for gene delivery. Colloids Surf. B Biointerfaces 2005, 44, 65-73. [CrossRef] [PubMed]

25. Bernkop-Schnürch, A.; Dünnhaupt, S. Chitosan-based drug delivery systems. Eur. J. Pharm. Biopharm. 2012, 81, 463-469. [CrossRef] [PubMed]

26. Dash, M.; Chiellini, F.; Ottenbrite, R.M.; Chiellini, E. Chitosan-A versatile semi-synthetic polymer in biomedical applications. Prog. Polym. Sci. 2011, 36, 981-1014. [CrossRef]

27. Karagozlu, M.Z.; Kim, S.K. Anticancer effects of chitin and chitosan derivatives. Adv. Food Nutr. Res. 2014, 72, 215-225. [CrossRef] [PubMed]

28. Martins, A.F.; Facchi, S.P.; Follmann, H.D.M.; Pereira, A.G.B.; Rubira, A.F.; Muniz, E.C. Antimicrobial activity of chitosan derivatives containing $N$-quaternized moieties in its backbone: A review. Int. J. Mol. Sci. 2014, 15, 20800-20832. [CrossRef] [PubMed]

29. Ngo, D.H.; Kim, S.K. Antioxidant effects of chitin, chitosan, and their derivatives. Adv. Food Nutr. Res. 2014, 73, 15-31. [CrossRef] [PubMed]

30. Sonaje, K.; Chuang, E.Y.; Lin, K.J.; Yen, T.C.; Su, F.Y.; Tseng, M.T.; Sung, H.W. Opening of epithelial tight junctions and enhancement of paracellular permeation by chitosan: Microscopic, ultrastructural, and computed-tomographic observations. Mol. Pharm. 2012, 9, 1271-1279. [CrossRef] [PubMed]

31. Kim, I.Y.; Seo, S.J.; Moon, H.S.; Yoo, M.K.; Park, I.Y.; Kim, B.C.; Cho, C.S. Chitosan and its derivatives for tissue engineering applications. Biotechnol. Adv. 2008, 26, 1-21. [CrossRef] [PubMed]

32. Ge, Y.; Zhang, Y.; He, S.; Nie, F.; Teng, G.; Gu, N. Fluorescence modified chitosan coated magnetic nanoparticles for high-efficient cellular imaging. Nanoscale Res. Lett. 2009, 4, 287-295. [CrossRef] [PubMed]

33. Agrawal, P.; Strijkers, G.J.; Nicolay, K. Chitosan-based systems for molecular imaging. Adv. Drug Deliv. Rev. 2010, 62, 42-58. [CrossRef] [PubMed]

34. Garcia-Fuentes, M.; Alonso, M.J. Chitosan-Based drug nanocarriers: Where do we stand? J. Control. Release 2012, 161, 496-504. [CrossRef] [PubMed] 
35. Croisier, F.; Jérôme, C. Chitosan-based biomaterials for tissue engineering. Eur. Polym. J. 2013, 49, 780-792. [CrossRef]

36. Ragelle, H.; Vandermeulen, G.; Preéat, V. Chitosan-based siRNA delivery systems. J. Control. Release 2013, 172, 207-218. [CrossRef] [PubMed]

37. Yang, Y.; Wang, S.; Wang, Y.; Wang, X.; Wang, Q.; Chen, M. Advances in self-assembled chitosan nanomaterials for drug delivery. Biotechnol. Adv. 2014, 32, 1301-1316. [CrossRef] [PubMed]

38. Ghaz-Jahanian, M.A.; Abbaspour-Aghdam, F.; Anarjan, N.; Berenjian, A.; Jafarizadeh-Malmiri, H. Application of Chitosan-Based Nanocarriers in Tumor-Targeted Drug Delivery. Mol. Biotechnol. 2015, 57, 201-218. [CrossRef] [PubMed]

39. Volpi, N.; Schiller, J.; Stern, R.; Soltés, L. Role, metabolism, chemical modifications and applications of hyaluronan. Curr. Med. Chem. 2009, 16, 1718-1745. [CrossRef] [PubMed]

40. Oh, E.J.; Park, K.; Kim, K.S.; Kim, J.; Yang, J.A.; Kong, J.H.; Lee, M.Y.; Hoffman, A.S.; Hahn, S.K. Target specific and long-acting delivery of protein, peptide, and nucleotide therapeutics using hyaluronic acid derivatives. J. Control. Release 2010, 141, 2-12. [CrossRef] [PubMed]

41. Sironen, R.K.; Tammi, M.; Tammi, R.; Auvinen, P.K.; Anttila, M.; Kosma, V.M. Hyaluronan in human malignancies. Exp. Cell Res. 2011, 317, 383-391. [CrossRef] [PubMed]

42. Menaa, F.; Menaa, A.; Menaa, B. Hyaluronic Acid and Derivatives for Tissue Engineering. J. Biotechnol. Biomater. 2011, S3, 1-7. [CrossRef]

43. Ossipov, D.A. Nanostructured hyaluronic acid-based materials for active delivery to cancer. Expert Opin. Drug Deliv. 2010, 7, 681-703. [CrossRef] [PubMed]

44. Jin, Y.J.; Ubonvan, T.; Kim, D.D. Hyaluronic Acid in Drug Delivery Systems. J. Pharm. Investig. 2010, 40, 33-43. [CrossRef]

45. Jiao, Y.; Pang, X.; Zhai, G. Advances in Hyaluronic Acid-Based Drug Delivery Systems. Curr. Drug Targets 2016, 17, 720-730. [CrossRef] [PubMed]

46. Knopf-Marques, H.; Pravda, M.; Wolfova, L.; Velebny, V.; Schaaf, P.; Vrana, N.E.; Lavalle, P. Hyaluronic Acid and Its Derivatives in Coating and Delivery Systems: Applications in Tissue Engineering, Regenerative Medicine and Immunomodulation. Adv. Healthc. Mater. 2016, 5, 2841-2855. [CrossRef] [PubMed]

47. Moon, M.; Thomas, R.G.; Heo, S.U.; Park, M.S.; Bae, W.K.; Heo, S.H.; Yim, N.Y.; Jeong, Y.Y. A Hyaluronic Acid-Conjugated Gadolinium Hepatocyte-Specific T1 Contrast Agent for Liver Magnetic Resonance Imaging. Mol. Imaging Biol. 2015, 17, 497-503. [CrossRef] [PubMed]

48. Payne, W.M.; Hill, T.K.; Svechkarev, D.; Holmes, M.B.; Sajja, B.R.; Mohs, A.M. Multimodal Imaging Nanoparticles Derived from Hyaluronic Acid for Integrated Preoperative and Intraoperative Cancer Imaging. Contrast Media Mol. Imaging 2017, 2017, 9616791. [CrossRef] [PubMed]

49. De la Fuente, M.; Seijo, B.; Alonso, M.J. Bioadhesive hyaluronan-chitosan nanoparticles can transport genes across the ocular mucosa and transfect ocular tissue. Gene Ther. 2008, 15, 668-676. [CrossRef] [PubMed]

50. De la Fuente, M.; Seijo, B.; Alonso, M.J. Novel hyaluronan-based nanocarriers for transmucosal delivery of macromolecules. Macromol. Biosci. 2008, 8, 441-450. [CrossRef] [PubMed]

51. De la Fuente, M.; Seijo, B.; Alonso, M.J. Design of novel polysaccharidic nanostructures for gene delivery. Nanotechnology 2008, 19, 075105. [CrossRef] [PubMed]

52. De la Fuente, M.; Seijo, B.; Alonso, M.J. Novel Hyaluronic Acid-Chitosan Nanoparticles for Ocular Gene Therapy. Investig. Ophthalmol. Vis. Sci. 2008, 49, 2016-2024. [CrossRef] [PubMed]

53. Jain, A.; Jain, S.K. In vitro and cell uptake studies for targeting of ligand anchored nanoparticles for colon tumors. Eur. J. Pharm. Sci. 2008, 35, 404-416. [CrossRef] [PubMed]

54. Duceppe, N.; Tabrizian, M. Factors influencing the transfection efficiency of ultra-low molecular weight chitosan/hyaluronic acid nanoparticles. Biomaterials 2009, 30, 2625-2631. [CrossRef] [PubMed]

55. Nasti, A.; Zaki, N.M.; de Leonardis, P.; Ungphaiboon, S.; Sansongsak, P.; Rimoli, M.G.; Tirelli, N. Chitosan/TPP and chitosan/TPP hyaluronic acid nanoparticles: Systematic optimisation of the preparative process and preliminary biological evaluation. Pharm. Res. 2009, 26, 1918-1930. [CrossRef] [PubMed]

56. Raviña, M.; Cubillo, E.; Olmeda, D.; Novoa-Carballal, R.; Fernandez-Megia, E.; Riguera, R.; Sánchez, A.; Cano, A.; Alonso, M.J. Hyaluronic Acid/Chitosan-g-poly(ethylene glycol) Nanoparticles for Gene Therapy: An Application for pDNA and siRNA Delivery. Pharm. Res. 2010, 27, 2544-2555. [CrossRef] [PubMed] 
57. Gwak, S.J.; Jung, J.K.; An, S.S.; Kim, H.J.; Oh, J.S.; Pennant, W.A.; Lee, H.Y.; Kong, M.H.; Kim, K.N.; Yoon, D.H.; et al. Chitosan/TPP-Hyaluronic Acid Nanoparticles: A New Vehicle for Gene Delivery to the Spinal Cord. J. Biomater. Sci. Polym. Ed. 2012, 23, 1437-1450. [CrossRef] [PubMed]

58. Deng, X.; Cao, M.; Zhang, J.; Hu, K.; Yin, Z.; Zhou, Z.; Xiao, X.; Yang, Y.; Sheng, W.; Wu, Y.; et al. Hyaluronic acid-chitosan nanoparticles for co-delivery of M1R-34a and doxorubicin in therapy against triple negative breast cancer. Biomaterials 2014, 35, 4333-4344. [CrossRef] [PubMed]

59. Lindborg, B.A.; Brekke, J.H.; Scott, C.M.; Chai, Y.W.; Ulrich, C.; Sandquist, L.; Kokkoli, E.; O’Brien, T.D. A chitosan-hyaluronan-based hydrogel-hydrocolloid supports in vitro culture and differentiation of human mesenchymal stem/stromal cells. Tissue Eng. Part A 2015, 21, 1952-1962. [CrossRef] [PubMed]

60. Qiao, Y.; Cheng, J.; Wu, G.; Lu, Q.; Yi, F.; Xu, J.; Zhu, J.; He, D. A Hyaluronic Acid-Chitosan-Gadolinium Nanosphere for Specific Tumor-Targeted MRI Contrast Agent. Gen. Chem. 2015, 1, 15-21. [CrossRef]

61. Courant, T.; Roullin, V.G.; Cadiou, C.; Callewaert, M.; Andry, M.C.; Portefaix, C.; Hoeffel, C.; de Goltstein, M.C.; Port, M.; Laurent, S.; et al. Hydrogels incorporating GdDOTA: Towards highly efficient dual T1/T2 MRI contrast agents. Angew. Chem. Int. Ed. 2012, 51, 9119-9122. [CrossRef] [PubMed]

62. Courant, T.; Roullin, V.G.; Cadiou, C.; Callewaert, M.; Andry, M.C.; Portefaix, C.; Hoeffel, C.; de Goltstein, M.C.; Port, M.; Laurent, S.; et al. Biocompatible Nanoparticles and Gadolinium Complexes for MRI applications. C. R. Chim. 2013, 16, 531-539. [CrossRef]

63. Callewaert, M.; Roullin, V.G.; Cadiou, C.; Millart, E.; Van Gulik, L.; Andry, M.C.; Portefaix, C.; Hoeffel, C.; Laurent, S.; Vander Elst, L.; et al. Tuning the composition of biocompatible Gd nanohydrogels to achieve hypersensitive dual T1/T2 MRI contrast agents. J. Mater. Chem. B 2014, 2, 6397-6405. [CrossRef]

64. Zhang, L.; Liu, T.; Xiao, Y.; Yu, D.; Zhang, N. Hyaluronic Acid-Chitosan Nanoparticles to Deliver Gd-DTPA for MR Cancer Imaging. Nanomaterials 2015, 5, 1379-1396. [CrossRef] [PubMed]

65. Zhang, L.; Liu, Y.; Yu, D.; Zhang, N. Gadolinium-Loaded Chitosan Nanoparticles as Magnetic Resonance Imaging Contrast Agents for the Diagnosis of Tumor. J. Biomed. Nanotechnol. 2013, 9, 863-869. [CrossRef] [PubMed]

66. Gheran, C.V.; Voicu, S.N.; Rigaux, G.; Callewaert, M.; Chuburu, F.; Dinischiotu, A. Biological effects induced by Gadolinium nanoparticles on Lymphocyte A20 cell line. EuroBiotech J. 2017, 1, 57-64. [CrossRef]

67. Rigaux, G.; Gheran, C.V.; Callewaert, M.; Cadiou, C.; Voicu, S.N.; Dinischiotu, A.; Andry, M.C.; Vander Elst, L.; Laurent, S.; Muller, R.N.; et al. Characterization of Gd loaded chitosan-TPP nanohydrogels by a multi-technique approach combining dynamic light scattering (DLS), asymetrical flow-field-flow fractionation (AF4) and atomic force microscopy (AFM) and design of positive contrast agents for molecular resonance imaging (MRI). Nanotechnology 2017, 28, 055705. [CrossRef] [PubMed]

68. Bradford, M.M. A rapid and sensitive method for the quantitation of microgram quantities of protein utilizing the principle of proteindye binding. Anal. Biochem. 1976, 72, 248-254. [CrossRef]

69. Legrand, C.; Bour, J.M.; Jacob, C.; Capiaumont, J.; Martial, A.; Marc, A.; Wudtke, M.; Kretzmer, G.; Demangel, C.; Duval, D. Lactate dehydrogenase (LDH) activity of the number of dead cells in the medium of cultured eukaryotic cells as marker. J. Biotechnol. 1992, 25, 231-243. [CrossRef]

70. Del Rio, D.; Pellegrini, N.; Colombi, B.; Bianchi, M.; Serafini, M.; Torta, F.; Tegoni, M.; Musci, M.; Brighenti, F. Rapid Fluorimetric method to detect total plasma malondialdehyde with mild derivatization conditions. Clin. Chem. 2003, 49, 690-692. [CrossRef] [PubMed]

71. Wimardani, Y.S.; Suniarti, D.F.; Freisleben, H.J.; Wanandi, S.I.; Ikeda, M.A. Cytotoxic effects of chitosan against oral cancer cell lines is molecular-weight-dependent and cell-type-specific. IJOR 2012, 3, e1.

72. Baharifar, H.; Amani, A. Cytotoxicity of chitosan/streptokinase nanoparticles as a function of size: An artificial neural networks study. Nanomedicine 2016, 12, 171-180. [CrossRef] [PubMed]

73. Lewinski, N.; Colvin, V.; Drezek, R. Cytotoxicity of nanoparticles. Small 2008, 4, 26-49. [CrossRef] [PubMed]

74. Manke, M.; Wang, L.; Rojanasakul, Y. Mechanisms of Nanoparticle-Induced Oxidative Stress and Toxicity. Biomed. Res. Int. 2013, 2013, 942916. [CrossRef] [PubMed]

75. Trachootham, D.; Lu, W.; Ogasawara, M.A.; Nilsa, R.D.; Huang, P. Redox Regulation of Cell Survival. Antioxid. Redox Signal. 2008, 10, 1343-1374. [CrossRef] [PubMed]

76. Dinkova-Kostova, A.T.; Abramov, A.Y. The emerging role of Nrf2 in mitochondrial function. Free Radic. Biol. Med. 2015, 88, 179-188. [CrossRef] [PubMed]

77. Fulda, S.; Gorman, AM.; Hori, O.; Samali, A. Cellular Stress Responses: Cell Survival and Cell Death. Int. J. Biochem. Cell Biol. 2010, 2010, 2140474. [CrossRef] [PubMed] 
78. Wen, Z.S.; Liu, L.J.; Qu, Y.L.; OuYang, X.K.; Yang, L.Y.; Xu, Z.R. Chitosan Nanoparticles Attenuate Hydrogen Peroxide-Induced Stress Injuryin Mouse Macrophage RAW264.7 Cells. Mar. Drugs 2013, 11, 3582-3600. [CrossRef] [PubMed]

79. Tamer, T.M.; Valachová, K.; Mohyeldin, M.S.; Soltes, L. Free radical scavenger activity of chitosan and its aminated derivative. J. Appl. Pharm. Sci. 2016, 6, 195-201. [CrossRef]

80. Wu, H.; Zhang, H.; Wang, C.; Wu, Y.; Xie, J.; Jin, X.; Yang, J.; Ye, J. Genoprotective effect of hyaluronic acid against benzalkonium chloride-induced DNA damage in human corneal epithelial cells. Mol. Vis. 2011, 17, 3364-3370. [PubMed]

81. Ye, J.; Wu, H.; Wu, Y.; Wang, C.; Zhang, H.; Shi, X.; Yang, J. High molecular weight hyaluronan decreases oxidative DNA damage induced by EDTA in human corneal epithelial cells. Eye 2012, 26, 1012-1020. [CrossRef] [PubMed]

(C) 2018 by the authors. Licensee MDPI, Basel, Switzerland. This article is an open access article distributed under the terms and conditions of the Creative Commons Attribution (CC BY) license (http://creativecommons.org/licenses/by/4.0/). 